\title{
Thermal stability improvement of metal oxide-based contacts for silicon heterojunction solar cells
}

Jinyoun $\mathrm{Cho}^{\mathrm{a}, \mathrm{b}, *, 1}$, Hariharsudan Sivaramakrishnan Radhakrishnan ${ }^{\mathrm{b}, *}$, Rajiv Sharma ${ }^{\mathrm{a}, \mathrm{b}}$, Maria Recaman Payo ${ }^{\mathrm{b}}$, Maarten Debucquoy ${ }^{\mathrm{b}}$, Arvid van der Heide ${ }^{\mathrm{b}}$, Ivan Gordon ${ }^{\mathrm{b}}$, Jozef Szlufcik ${ }^{\mathrm{b}}$, and Jef Poortmans $s^{\mathrm{a}, \mathrm{b}, \mathrm{c}}$

${ }^{\text {a} E S A T ~ d e p a r t m e n t, ~ K . U . ~ L e u v e n, ~ K a s t e e l p a r k ~ A r e n b e r g ~ 10, ~ L e u v e n ~ 3001, ~ B e l g i u m ~}$

${ }^{b}$ imec (partner in EnergyVille), Kapeldreef 75, Leuven 3001, Belgium

${ }^{c}$ University Hasselt, Martelarenlaan 42, Hasselt 3500, Belgium

*Current email address of the corresponding author: jinyoun.cho@eu.umicore.be

1. Current address: Umicore, Watertorenstraat 33, B-2250 Olen, Belgium

Keywords: doping-free cells, passivating contact, $\mathrm{TiO}_{\mathrm{x}}, \mathrm{MoO}_{\mathrm{x}}$, thermal stability, annealing 


\begin{abstract}
Metal oxides are interesting materials for use as carrier-selective contacts for the fabrication of doping-free silicon solar cells. In particular, $\mathrm{MoO}_{\mathrm{x}}$ and $\mathrm{TiO}_{\mathrm{x}}$ have been successfully used as hole and electron selective contacts in silicon solar cells, respectively. However, it is of paramount importance that good thermal stability is achieved in such contacts. In our work, we combined i-a-Si:H/MoO $\mathrm{M}_{\mathrm{x}}$ based hole contacts with electron contacts featuring i-a$\mathrm{Si}: \mathrm{H} / \mathrm{TiO}_{\mathrm{x}} / \mathrm{low}$ work function metal (ATOM) to fabricate doping-free cells, termed MolyATOM cells. We found that the thermal stability of the ATOM contact was improved when the $\mathrm{i}-\mathrm{a}-\mathrm{Si}: \mathrm{H}$ was annealed $\left(300{ }^{\circ} \mathrm{C}\right.$ for $20 \mathrm{~min}$ in $\mathrm{N}_{2}$ ) before depositing $\mathrm{TiO}_{\mathrm{x}}$ (i.e. pre- $\mathrm{TiO}_{\mathrm{x}}$ annealing), which reduces the hydrogen content in $\mathrm{i}-\mathrm{a}-\mathrm{Si}: \mathrm{H}$ by about $27 \%$ rel, and thereby the H-related degradation of the ATOM contact characteristics. Moreover, it was found that reducing the thickness of the low-work function metal on top of the $\mathrm{TiO}_{\mathrm{x}}$ enhanced the thermal stability of the ATOM contact. With these adaptations, the MolyATOM cell efficiency was improved by $3.5 \%$ abs, with the highest efficiency of $17.6 \%$. Moreover, the cells show improved thermal stability after the above-mentioned pre- $\mathrm{TiO}_{\mathrm{x}}$ annealing, which is confirmed by annealing tests at cell level as well as damp-heat tests at module level. The insights of this study could be used to tailor other metal-oxide based electron or hole contacts.
\end{abstract}

\title{
1. Introduction
}

Photovoltaics (PV) is gaining more importance worldwide, and has become the largest newly installed renewable energy source with newly installed capacity in 2018 of more than $100 \mathrm{GWp}$ [1]. Today crystalline silicon (c-Si)-based PV modules occupy a market share above $95 \%$ of the annually installed PV capacity [2]. Research in the field of c-Si solar cells is focused on getting higher efficiencies, combined with lower PV module prices [3]. Higher efficiencies can be achieved by minimising the total recombination current densities $\left(\mathrm{J}_{0, \text { total }}\right)$ in the solar cell, which is the sum of recombination current densities at the passivated surfaces $\left(\mathrm{J}_{0, \text { passi }}\right)$, at the metallized areas of the surfaces $\left(\mathrm{J}_{0, \text { metal }}\right)$ as well as in the bulk $\left(\mathrm{J}_{0, \text { bulk }}\right)$. Currently, homojunction solar cells, such as aluminum back-surface-field (Al-BSF), passivated emitter and rear cells (PERC), and passivated emitter and rear totally diffused (PERT) solar cells, are dominant in the market [4]. In these solar cells, metal-semiconductor (MS) contacts are made on the heavily doped Si regions. This results in high recombination current densities at the metalized areas $\left(\mathrm{J}_{0 \text {,metal }}\right.$ ), which range from about a few hundred to a few thousand $\mathrm{fA} / \mathrm{cm}^{2}$ depending on the cell technology [5-8]. The high $\mathrm{J}_{0, \text { total }}$ caused by a full-area rear MS contact in Al-BSF solar cells is addressed by implementing local contact structures in the PERC [9] and PERT [10] cells. This reduces the metallized area fraction and hence the contribution of $\mathrm{J}_{0 \text {, metal }}$ to $\mathrm{J}_{0 \text {,total }}$, thereby enabling improved efficiencies compared to Al-BSF cells. Since $\mathrm{J}_{0 \text {,passi }}$ below $20 \mathrm{fA} / \mathrm{cm}^{2}$ can be readily achieved for both phosphorus-doped and boron-doped surfaces [11], $\mathrm{J}_{0 \text {,metal }}$ is the main factor limiting the achievable cell efficiency in these homojunction solar cells. Lowering the contribution of $\mathrm{J}_{0 \text {,metal }}$ further by reducing the metal contact area even more would lead to increased contact resistance $\left(R_{C}\right)$ i.e. there is a trade-off between $J_{0, \text { total }}$ and $R_{C}$. 
The current approach in the field of silicon photovoltaics to achieve both low $\mathbf{J}_{0 \text {,metal }}$ and low contact resistivity $\left(\rho_{c}\right)$ is through the implementation of a passivating contact, whereby the passivating layer is part of the contact scheme. Representative examples of such passivating contacts are silicon heterojunctions (SHJ) based on hydrogenated amorphous or nanocrystalline silicon (a-Si:H or nc-Si:H) with a transparent conductive oxide (TCO) $[12,13]$ as well as contacts based on poly-Si on an ultra-thin oxide (i.e. TOPCon or POLO) $[14,15]$. Both SHJ solar cells and the cells with poly-Si/oxide passivating contacts have demonstrated efficiencies above $25 \%$, due to the excellent contact passivation and the resulting low $\mathrm{J}_{0 \text {,metal }}$, combined with the low $\rho_{\mathrm{c}}$ achieved in these solar cells $[12,14,16]$. Therefore, these contact schemes are intensively studied for industrial implementation [17].

These passivating contacts generally require the deposition of a doped layer (e.g. plasmaenhanced chemical vapor deposition (PECVD) of doped a-Si or low-pressure CVD (LPCVD) of in situ doped poly-Si) or a doping process (e.g. diffusion or implantation of dopants into intrinsic poly-Si). A novel approach for realizing passivating contacts that is of interest in the $\mathrm{PV}$ research community is the fabrication of cells without such doping processes or deposition of doped layers. By applying certain metal compounds, particularly transition metal oxides (TMOs), in place of such doped layers, carrier selectivity can be achieved at the contacts by virtue of their band structure, and their low or high work function with respect to c-Si. One of the benefits of this approach is that the manufacturing process could be simplified due to the absence of doping processes and critical pre- and post-diffusion cleaning steps. Moreover, optoelectrical losses occurring in the heavily doped regions can be avoided by replacing the doped layers with the aforementioned high bandgap metal compounds.

For doping-free hole contacts, several high work function materials were proposed, such as $\mathrm{MoO}_{\mathrm{x}}, \mathrm{VO}_{\mathrm{x}}, \mathrm{WO}_{\mathrm{x}}, \mathrm{NiO}_{\mathrm{x}}$, and $\mathrm{CuI}$ [18-21], however, only $\mathrm{MoO}_{\mathrm{x}}$ with an intrinsic a-Si:H (i-a$\mathrm{Si}: \mathrm{H})$ buffer layer on c-Si could achieve high solar cell efficiencies above $20 \%$ [22-25]. Without the $\mathrm{i}-\mathrm{a}-\mathrm{Si}: \mathrm{H}$ buffer layer, $\mathrm{MoO}_{\mathrm{x}}$ can induce stronger upward band bending at the hole contact region of $\mathrm{c}-\mathrm{Si}$, which is beneficial for charge transport [26], however it also results in poor passivation quality which limits the cell efficiency [27]. Therefore, many studies were aimed at replacing only the p-type a-Si:H (p-a-Si:H) in the i/p-a-Si:H stack of SHJ cells with $\mathrm{MoO}_{\mathrm{x}}$. The high bandgap of $\mathrm{MoO}_{\mathrm{x}}$ reduces the parasitic absorption at short wavelength region and its high work function induces upward band bending for efficient hole collection, in a similar way to p-a-Si:H in SHJ cells [24]. In this work, we too study $\mathrm{MoO}_{\mathrm{x}}$ on $\mathrm{i}-\mathrm{a}-\mathrm{Si}: \mathrm{H}$ as the hole contact.

For doping-free electron contacts, relatively many material options are available. Metal oxides (e.g. $\mathrm{TiO}_{\mathrm{x}}$ ) [28-31], metal nitrides (e.g. TaN) [32,33], metal fluorides (e.g. $\mathrm{LiF}$ ) [34-36] or a combination of those layers with low work function metals (e.g. Ca or Yb) [37-44] have been studied. In theory, when a metal is directly in contact with c-Si or a-Si:H, a large number of surface states are created at the interface. As a result, the Fermi level of the metal $\left(\mathrm{E}_{\mathrm{F}, \mathrm{metal}}\right)$ is pinned at a certain energy level of semiconductor regardless of work function of metals $[45,46]$. This can lead to weak or undesired band bending of semiconductor, and result in high $\rho_{\mathrm{c}}$. To 
depin the $\mathrm{E}_{\mathrm{F} \text {,metal }}$ on c-Si or a-Si:H, a thin metal oxide can be introduced between the metal and the semiconductor (i.e. c-Si or a-Si:H) [47,48]. Previously, we have reported on the development of a unique electron contact stack featuring $\mathrm{i}-\underline{a}-\mathrm{Si}: \mathrm{H} / \underline{\mathrm{TiO}} \mathrm{x} /$ low work function metal, in short, ATOM contact [39-41,48,49]. The i-a-Si:H layer ensures excellent contact passivation with a low $\mathrm{J}_{0 \text {, metal }}$ of less than $25 \mathrm{fA} / \mathrm{cm}^{2}$, while the $\mathrm{TiO}_{\mathrm{x}}$ layer is used to eliminate the Fermi level $\left(E_{F}\right)$ pinning of the low work function metals (e.g. Ca or $\mathrm{Yb}$ ) on the $\mathrm{i}-\mathrm{a}-\mathrm{Si}: \mathrm{H}$ surface, which enables a low $\rho_{c}$ of below $0.1 \Omega \cdot \mathrm{cm}^{2}$ to be attained [38-41]. In this work, we study the ATOM contact with $\mathrm{Yb}\left(\Phi_{\text {metal }} 2.5 \mathrm{eV}\right)$ as the low work function metal.

Thermal instability of doping-free electron and hole selective contacts based on TMOs has been widely reported in literature. For instance, it has been reported that annealing treatments on the $\mathrm{TiO}_{\mathrm{x}} / \mathrm{Ti}$ contact on c-Si causes oxygen migration from $\mathrm{TiO}_{\mathrm{x}}$ to the $\mathrm{Ti}$ metal, leading to the conversion of $\mathrm{TiO}_{\mathrm{x}}$ to semimetallic $\mathrm{TiO}$. This leads to high $\rho_{\mathrm{c}}$ due to the reappearance of $\mathrm{E}_{\mathrm{F} \text {,metal }}$ pinning [50]. We have reported in our earlier work on the increase in $\rho_{c}$ of the ATOM contact stack based on $\mathrm{TiO}_{\mathrm{x}} / \mathrm{Yb} / \mathrm{Ag}$ on a-Si:H when a thermal treatment was applied [41].

Similarly, there have been many studies reporting on the degradation observed in hole selective contacts featuring $\mathrm{i}-\mathrm{a}-\mathrm{Si}: \mathrm{H} / \mathrm{MoO}_{\mathrm{x}}$. The degradation mechanism is apparently related to oxygen loss in the $\mathrm{MoO}_{\mathrm{x}}$ layer due to reaction with hydrogen from the i-a-Si:H layer [27,51]. Changes in the stoichiometry of $\mathrm{MoO}_{\mathrm{x}}$ directly affect the work function of $\mathrm{MoO}_{\mathrm{x}}$ [52], and thus, the band bending at the c-Si surface and hole collection. One suggested a solution to this problem is to pre-anneal the i-a-Si:H layer at $250{ }^{\circ} \mathrm{C}$ in $\mathrm{N}_{2}$ for 20 min before $\mathrm{MoO}_{\mathrm{x}}$ deposition. With this approach, reduced degradation of $\mathrm{MoO}_{x}$ and increased cell efficiencies have been reported [27].

\section{MolyATOM cell}

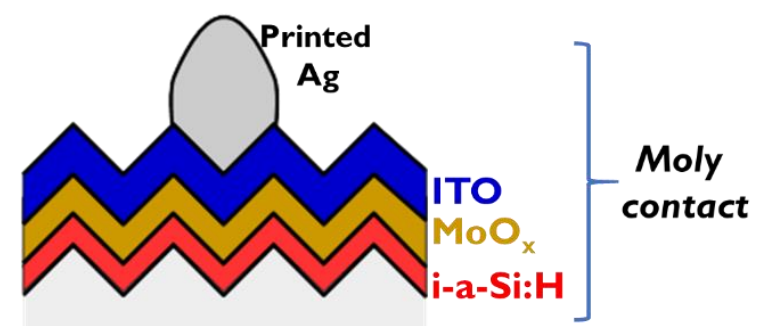

Czn-Si

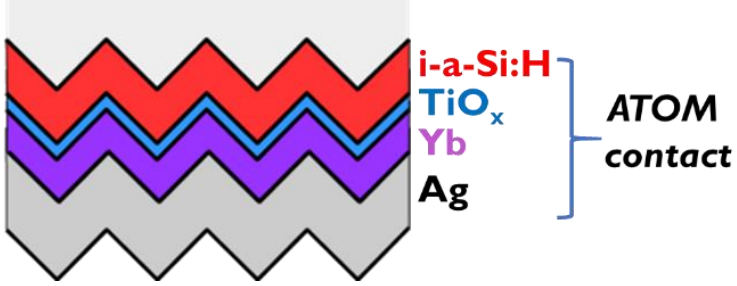

Figure 1. A schematic cross-section of the fully doping-free MolyATOM cell. 
Building on the understanding gathered from the i-a-Si:H/MoO $\mathrm{O}_{\mathrm{x}}$ based hole contact, the first goal of this paper is to gain further insight into the role of hydrogen in the degradation observed in the ATOM electron contact based on $\mathrm{i}-\mathrm{a}-\mathrm{Si}: \mathrm{H} / \mathrm{TiO}_{\mathrm{x}} / \mathrm{Yb} / \mathrm{Ag}$. The impact of pre-annealing the $\mathrm{i}-\mathrm{a}-\mathrm{Si}: \mathrm{H}$ layer on the thermal stability of the ATOM contact is investigated in terms of $\rho_{\mathrm{c}}$. Additionally, it was found that the thickness of the low work function metal affected the thermal stability of the ATOM contact via an increase in $\rho_{c}$.

The second goal of this paper is to demonstrate , after determining the optimal pre-annealing conditions to ensure high thermal stability, fully doping-free cells, shortly called MolyATOM cells (Molybdenum oxide-based hole contact $+\underline{\text { ATOM }}$ electron contact, shown in Figure 1), whereby the doped layers on both the electron and hole contacts were replaced by TMOs. The thermal stability of the MolyATOM cells was evaluated at cell and module level.

2. Experimental methods

2.1. Effect of annealing i-a-Si:H on contact resistivity of ATOM contacts

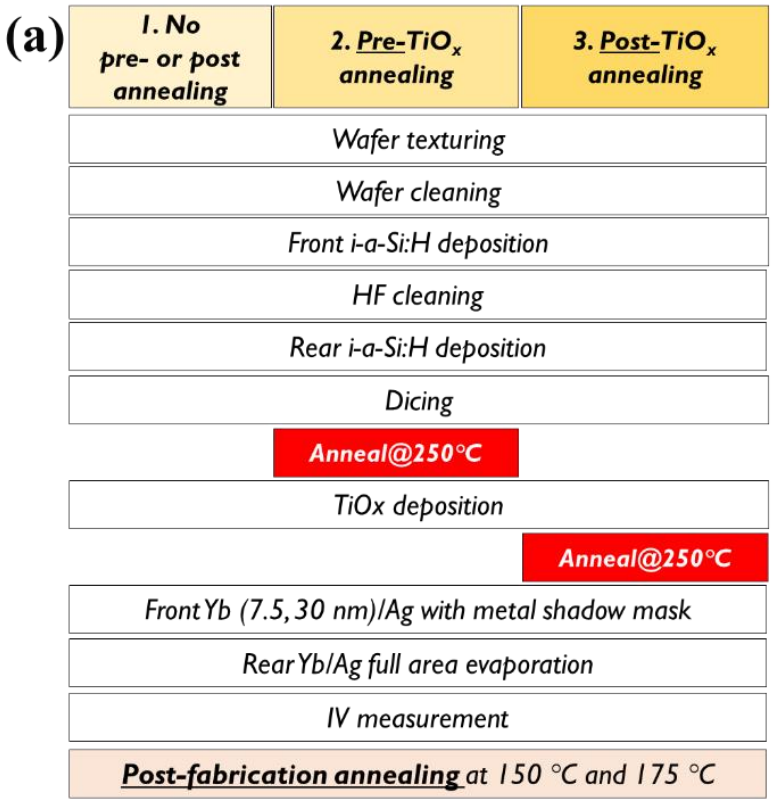

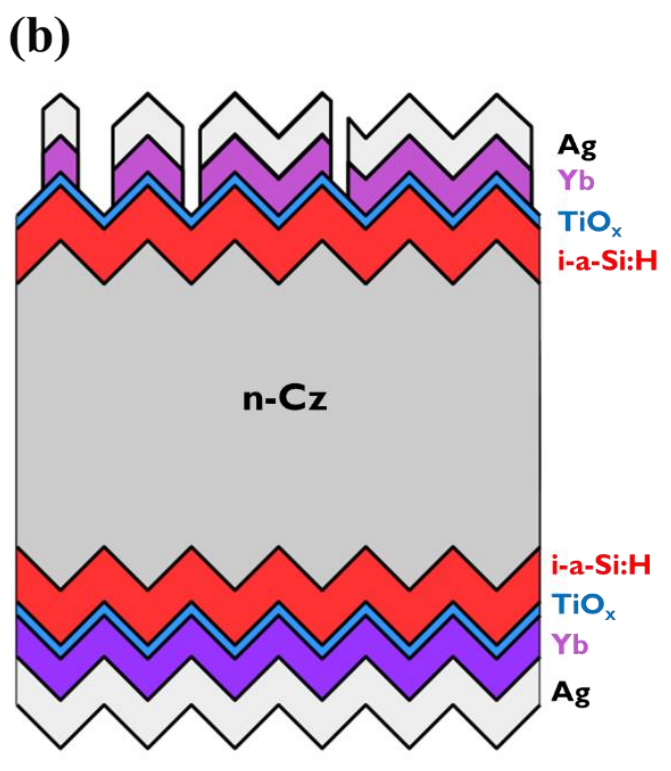

Figure 2. (a) Process flow for studying pre-and post-TiO annealing effect on $\rho_{c}$, and (b) a schematic sample structure for this study.

For evaluating the impact of annealing the $\mathrm{i}-\mathrm{a}-\mathrm{Si}$ layer before and after $\mathrm{TiO}_{\mathrm{x}}$ deposition on the $\rho_{\mathrm{c}}$ of ATOM contacts, test samples were prepared using double-side textured $(3 \Omega \cdot \mathrm{cm}, 180 \mu \mathrm{m}$ thickness after texturing process) n-type $\mathrm{Cz}$-Si wafers. The process flow used to fabricate these test samples and their cross-sectional structure are depicted in Figure 2. After wafer cleaning using $\mathrm{O}_{3} / \mathrm{HCl} /$ deionized water and $\mathrm{HF} / \mathrm{HCl}$ solutions, $8 \mathrm{~nm}$ thick i-a-Si:H was deposited by PECVD on the front side. After HF cleaning, an i-a-Si:H layer of $8 \mathrm{~nm}$ was deposited on the rear side of all samples. $\mathrm{TiO}_{\mathrm{x}}$ of $1 \mathrm{~nm}$ was deposited by atomic layer deposition (ALD) using $\mathrm{Ti}\left(\mathrm{OCH}_{3}\right)_{4}$ and $\mathrm{H}_{2} \mathrm{O}$ as Ti precursor and oxidant, respectively. Two groups of the sample were 
annealed at $250{ }^{\circ} \mathrm{C}$ for 20 min in $\mathrm{N}_{2}$ using rapid thermal annealing (RTA) before and after $\mathrm{TiO}_{\mathrm{x}}$ deposition, respectively, and one group was not annealed at all. Then, the wafers were diced to the size of $3 \mathrm{~cm} \times 3 \mathrm{~cm}$ for $\rho_{\mathrm{c}}$ measurement. Two thicknesses of $Y b(7.5 \mathrm{~nm}$ and $30 \mathrm{~nm})$ with a fixed $\mathrm{Ag}$ thickness of $100 \mathrm{~nm}$ were evaporated without breaking vacuum on the front side of different samples through a metal shadow mask to form circular dots of different diameters. For the rear side, full area $\mathrm{Yb}$ of $30 \mathrm{~nm}$ and $\mathrm{Ag}$ of $100 \mathrm{~nm}$ were deposited using the same technique. At the end of the fabrication sequence, additional annealing treatments were done at $150^{\circ} \mathrm{C}$ and $175^{\circ} \mathrm{C}$. The method for determining $\rho_{\mathrm{c}}$ using the test structure shown in Figure $2(\mathrm{~b})$ is explained in the elsewhere $[38,41]$.

2.2. Solar cell fabrication

\begin{tabular}{|c|c|c|}
\hline MolyATOM & Molylin & Classical SHJ \\
\hline \multicolumn{3}{|c|}{ Wafer texturing } \\
\hline \multicolumn{3}{|c|}{ Wafer cleaning } \\
\hline \multicolumn{2}{|c|}{ Front i-a-Si:H deposition } & Front i/p-a-Si:H \\
\hline \multicolumn{3}{|c|}{ HF cleaning } \\
\hline Rear i-a-Si:H deposition & \multicolumn{2}{|c|}{ Rear i/n-a-Si:H deposition } \\
\hline Pre-ann.@ 200,250, 300 C & \multicolumn{2}{|c|}{ Pre-ann.@300ㄷ } \\
\hline \multicolumn{3}{|l|}{$\mathrm{TiO}_{x}$ deposition } \\
\hline Front vapor HF & \multicolumn{2}{|l|}{ HF cleaning } \\
\hline \multicolumn{3}{|c|}{$\mathrm{MoO}_{x}$ evaporation } \\
\hline Front ITO & \multicolumn{2}{|c|}{ Front and rear ITO } \\
\hline Front Ag screen print & \multicolumn{2}{|c|}{ Front and rear Ag screen print } \\
\hline \multicolumn{3}{|c|}{ Sintering@160 다 } \\
\hline
\end{tabular}

RearYb $(7.5 \mathrm{~nm}) / \mathrm{Ag}$ evaporation

Post-fabrication ann.@150 ${ }^{\circ} \mathrm{C}$

Figure 3. Process flow for the fabrication of different solar cells reported in this paper: MolyATOM, Moly/in and classical SHJ cells.

Three types of solar cells were prepared, namely 1) MolyATOM cells (with i-a-Si:H/MoO $\mathrm{x}_{\mathrm{x}}$ hole contact and $\mathrm{i}-\mathrm{a}-\mathrm{Si}: \mathrm{H} / \mathrm{TiO}_{\mathrm{x}} / \mathrm{Yb} / \mathrm{Ag}$ as ATOM electron contact), 2) Moly/in cells (with i-a$\mathrm{Si}: \mathrm{H} / \mathrm{MoO}_{\mathrm{x}}$ as hole contact and $\mathrm{i} / \mathrm{n}-\mathrm{a}-\mathrm{Si}: \mathrm{H}$ stack as electron contact), and 3) classical SHJ cells (with $\mathrm{i} / \mathrm{p}-\mathrm{a}-\mathrm{Si}: \mathrm{H}$ and $\mathrm{i} / \mathrm{n}-\mathrm{a}-\mathrm{Si}: \mathrm{H}$ stacks as hole and electron contacts, respectively). The respective process flows for the fabrication of these solar cells is given in Figure 3. Double-side textured ( $3 \Omega \cdot \mathrm{cm}, 180 \mu \mathrm{m}$ thickness after texturing process) n-type Cz-Si wafers were used. 
After cleaning the textured wafers, an i-a-Si:H layer was deposited on the front for MolyATOM and Moly/in cells while an i/p-a-Si:H stack was deposited on the same side for classical SHJ cells. After HF cleaning, i-a-Si:H was deposited on the rear for the MolyATOM cells while an i/n-a-Si:H stack was deposited for the Moly/in and classical SHJ cells.

Afterward, for the $1^{\text {st }}$ study about pre-annealing conditions, 3 groups of wafers from the MolyATOM split were pre-annealed using rapid thermal annealing (RTA) at $200{ }^{\circ} \mathrm{C}, 250{ }^{\circ} \mathrm{C}$ and $300{ }^{\circ} \mathrm{C}$, respectively, for $20 \mathrm{~min}$ in $\mathrm{N}_{2}$ atmosphere, while a fourth group was not annealed at all. For the $2^{\text {nd }}$ study about the comparison of MolyATOM with classical SHJ cells, one group of MolyATOM cells was pre-annealed at $300{ }^{\circ} \mathrm{C}$. One group of wafers from the Moly/in split was also pre-annealed at $300{ }^{\circ} \mathrm{C}$ under the same conditions, while the other Moly/in wafers were not. For the classical SHJ wafers, no pre-annealing was carried out.

On the rear-side of the MolyATOM wafers, a $1 \mathrm{~nm}$ thick $\mathrm{TiO}_{\mathrm{x}}$ layer was deposited using ALD. Then, a vapor HF process or an HF cleaning was performed on the wafers of the MolyATOM and the Moly/in splits, respectively. Vapor HF allows one-sided native oxide removal on the front-side of the MolyATOM wafers without affecting the $\mathrm{TiO}_{\mathrm{x}}$ on the rear-side. After a $\mathrm{MoO}_{\mathrm{x}}$ evaporation of $6 \mathrm{~nm}$ on the front-side for the MolyATOM and Moly/in splits, ITO deposition and Ag screen-printing were done for all cell types on the front-side. For the rear-side, ITO sputtering and Ag screen-printing were done only for the Moly/in and classical SHJ splits. Sintering was then carried out on all cells including the MolyATOM devices using a belt furnace in $\mathrm{N}_{2}$ at $160{ }^{\circ} \mathrm{C}$ to increase the conductivity of the printed $\mathrm{Ag}$ grid on the front-side and to recover the sputtering damage from ITO deposition. For the MolyATOM split, an Yb/Ag stack was thermally evaporated on the rear-side without breaking vacuum.

Illuminated IV characteristics were measured with an aperture opening of the same size as the cell area of $4 \times 4 \mathrm{~cm}^{2}$ at standard 1 sun conditions (AM $1.5 \mathrm{G}, 1000 \mathrm{~W} / \mathrm{m}^{2}$ at $25^{\circ} \mathrm{C}$ ). External quantum efficiency (EQE) and reflectance (R) were measured using an illumination spot size of $1.5 \times 1.5 \mathrm{~cm}^{2}$. Therefore, the EQE and reflectance results include the shading and reflection effects of the front metal grid. A post-fabrication anneal was performed on part of the cells at $150{ }^{\circ} \mathrm{C}$ for varied durations.

\subsection{Evaluation of hydrogen content in i-a-Si:H}

The evolution of the hydrogen content in i-a-Si:H after annealing at $200{ }^{\circ} \mathrm{C}, 250{ }^{\circ} \mathrm{C}$ and $300{ }^{\circ} \mathrm{C}$ was investigated using elastic recoil detection (ERD) on a $30 \mathrm{~nm}$ thick a-Si:H layer deposited using PECVD on mirror polished $730 \mu \mathrm{m}$ thick $\mathrm{Cz}$ wafers.

\subsection{Mini-module fabrication}


(a) As-fabricated module

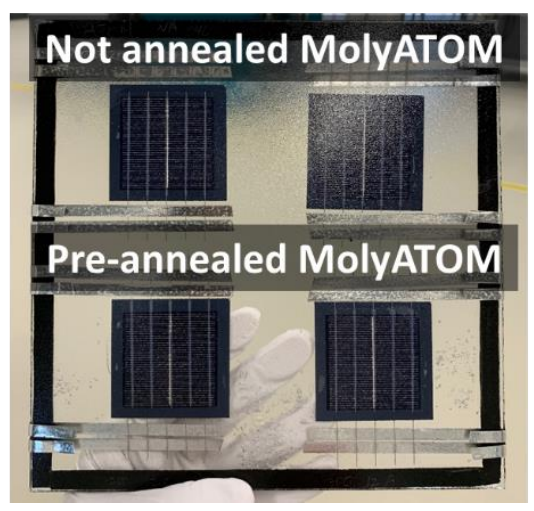

(b)

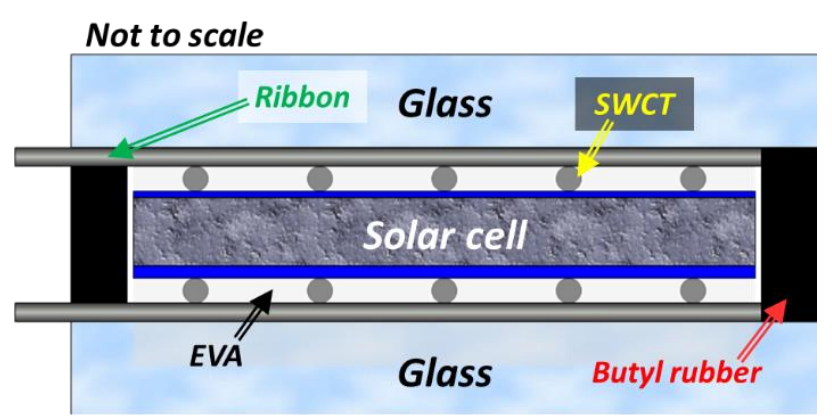

Figure 4. (a) As-fabricated state the mini-module and (b) a schematic cross-sectional image of the mini-module.

A mini-module (glass/glass) was fabricated using the MolyATOM cells with an Yb thickness of $7.5 \mathrm{~nm}$ with and without pre-anneal treatment at $300^{\circ} \mathrm{C}$. The four cells in the mini-module shown in Figure 4 (a) are not interconnected. An UV-blocking ethylene vinyl acetate (EVA) sheet, a smart-wire connection technology (SWCT) foil (from Meyer Burger) and glass were used. A solder-coated ribbon was used to connect the smart wires and bring the electrical contacts of each individual cell to outside of the mini-module, so that each one can be measured individually. A butyl rubber tape was applied for hermetic sealing at the edges. The lamination process was carried out at $150^{\circ} \mathrm{C}$ for about $20 \mathrm{~min}$. During the course of the damp heat test $\left(85{ }^{\circ} \mathrm{C} / 85 \%\right.$ humidity/1000 hour), illuminated IV curves (AM $1.5,1000 \mathrm{~W} / \mathrm{m}^{2}$ at $25^{\circ} \mathrm{C}$ ) were measured after every 250 hours. An aperture area of $4 \times 4 \mathrm{~cm}^{2}$ was used for these measurements by using an opaque black tape around the edge of the active cell area. The same module structure and test method were reported in reference [20].

\section{Improving the thermal stability of the ATOM contact}

As noted earlier, deterioration in $\rho_{\mathrm{c}}$ of the ATOM contact, based on $\mathrm{TiO}_{\mathrm{x}} / \mathrm{Yb} / \mathrm{Ag}$ on a-Si:H, by about an order of magnitude upon annealing at $150{ }^{\circ} \mathrm{C}$ or $180^{\circ} \mathrm{C}$ has been reported previously [41]. Thus, finding a way to improve the thermal stability of the ATOM contact is necessary. It is postulated that the mechanism behind this thermal degradation is related to the reduction of $\mathrm{TiO}_{\mathrm{x}}$, which could occur due to the reaction between $\mathrm{H}$ in a-Si:H and $\mathrm{O}$ in $\mathrm{TiO}_{\mathrm{x}}$, or due to $\mathrm{O}$ migration towards the low work function metal on the other side. In addition, $\mathrm{TiO}_{\mathrm{x}}$ may undergo microstructural changes upon annealing.

For these reasons, annealing treatments before (labeled pre- $\mathrm{TiO}_{\mathrm{x}}$ anneal) and after $\mathrm{TiO}_{\mathrm{x}}$ deposition (post- $\mathrm{TiO}_{\mathrm{x}}$ anneal) were tested as possible means to improve the thermal stability. The idea is that a pre- $\mathrm{TiO}_{\mathrm{x}}$ anneal could dehydrogenate the $\mathrm{i}-\mathrm{a}-\mathrm{Si}: \mathrm{H}$ layer and therefore mitigate the reaction between $\mathrm{H}$ in $\mathrm{i}-\mathrm{a}-\mathrm{Si}: \mathrm{H}$ and $\mathrm{O}$ in $\mathrm{TiO}_{\mathrm{x}}$. A post- $\mathrm{TiO}_{\mathrm{x}}$ anneal, on the other hand, could stabilize the microstructure of $\mathrm{TiO}_{\mathrm{x}}$ before deposition of the low work function metal, such that 
$\mathrm{O}$ migration to the interface with the low work function metal or the a-Si:H can be inhibited, thereby minimizing thermal degradation.

As a method for evaluating thermal stability, the change in $\rho_{c}$ of the ATOM contact was evaluated after post-fabrication annealing consecutively at $150{ }^{\circ} \mathrm{C}$ and $175^{\circ} \mathrm{C}$ for $10 \mathrm{~min}$ each. In addition, different $\mathrm{Yb}$ thicknesses of $7.5 \mathrm{~nm}$ and $30 \mathrm{~nm}$ were tested to investigate the impact on thermal stability of the ATOM contact in terms of $\rho_{c}$. Since loss of hydrogen from a-Si:H could affect the passivation quality, the evolution of the implied $\mathrm{V}_{\mathrm{OC}}\left(\mathrm{iV}_{\mathrm{OC}}\right.$ ) and the $\mathrm{J}_{0, \text { total }}$ of cell precursors was also monitored as a function of the pre-annealing temperature.

\subsection{Hydrogen content of $\mathrm{i}-\mathrm{a}-\mathrm{Si}: \mathrm{H}$ after annealing at different temperatures}

Pre-annealing of i-a-Si:H at $250{ }^{\circ} \mathrm{C}$ for 20 min during the fabrication of solar cells with i-a$\mathrm{Si}: \mathrm{H} / \mathrm{MoO}_{\mathrm{x}}$ based hole contacts was reported to result in higher thermal stability and cell efficiency [27]. While we may expect a similar effect for our ATOM electron contact, the optimal conditions for this pre-annealing treatment would depend on the properties of the asgrown a-Si:H layer and the details of its interaction with $\mathrm{TiO}_{\mathrm{x}}$. Thus, in our work, various preannealing temperatures were tested.

Annealing of $\mathrm{i}-\mathrm{a}-\mathrm{Si}: \mathrm{H}$, prior to capping it with metal layers, leads to effusion of hydrogen and concomitant reduction in its hydrogen content. ERD measurements can be used to determine the hydrogen content in a-Si:H films. The concentration of hydrogen in a $30 \mathrm{~nm}$ thick i-a-Si:H film was determined in the as-deposited state and then after annealing at different temperatures of $200{ }^{\circ} \mathrm{C}, 250{ }^{\circ} \mathrm{C}$ and $300{ }^{\circ} \mathrm{C}$ for $20 \mathrm{~min}$, and the results are summarised in Table 1.

Table 1. The hydrogen concentration in a-Si:H of $30 \mathrm{~nm}$ thickness after annealing at different temperatures for 20 min, determined using ERD measurements.

\begin{tabular}{ccccc}
\hline Annealing temperature & No annealing & $\mathbf{2 0 0}{ }^{\circ} \mathbf{C}$ & $\mathbf{2 5 0}{ }^{\circ} \mathbf{C}$ & $\mathbf{3 0 0}{ }^{\circ} \mathbf{C}$ \\
\hline H (at \%) & $15.7 \pm 2$ & $14.3 \pm 1$ & $14.0 \pm 1$ & $11.4 \pm 1$ \\
Si (at \%) & $84.3 \pm 2$ & $85.7 \pm 2$ & $86.0 \pm 2$ & $88.6 \pm 2$ \\
$\left(\mathbf{H} / \mathbf{H}_{\text {non-annealed }) \mathbf{- 1}(\% \text { rel })}\right.$ & - & -9 & -11 & -27 \\
\hline
\end{tabular}

The as-deposited film has a high $\mathrm{H}$ concentration of approximately $15.7 \%$, and annealing the film results in a loss of hydrogen at all investigated temperatures. This proves that indeed $\mathrm{H}$ effuses out of the a-Si:H film upon annealing at these temperatures. The higher the temperature, the greater the loss of $\mathrm{H}$ from the film. While annealing at $200{ }^{\circ} \mathrm{C}$ and $250{ }^{\circ} \mathrm{C}$ results in a loss of $\mathrm{H}$ of around $10 \%$ rel, a sharp reduction in $\mathrm{H}$ of $27 \%$ rel is observed when annealing at $300{ }^{\circ} \mathrm{C}$. 
While a $30 \mathrm{~nm}$ thick i-a-Si:H film was used for this study, the phenomenon is expected to be similar for an $8 \mathrm{~nm}$ thick film.

\subsection{Effect of pre- and post-TiO ${ }_{x}$ annealing on thermal stability of the ATOM contact as monitored via $\rho_{c}$}

To study the impact of annealing the i-a-Si:H layer on the $\rho_{\mathrm{c}}$ of the ATOM contact, a fixed preannealing temperature of $250{ }^{\circ} \mathrm{C}$ for 20 min was used (see Figure 2 (a)). The $\rho_{c}$ results of the ATOM contact are summarised in Figure 5. To minimize series resistance losses, $\rho_{c}$ should be as low as possible. However, an upper limit for $\rho_{\mathrm{c}}$ of $0.1 \Omega \cdot \mathrm{cm}^{2}$ was set, at which significant $\mathrm{V}_{\mathrm{OC}}$ losses are expected due to non-negligible potential drop at the contact $[53,54]$.

(a)

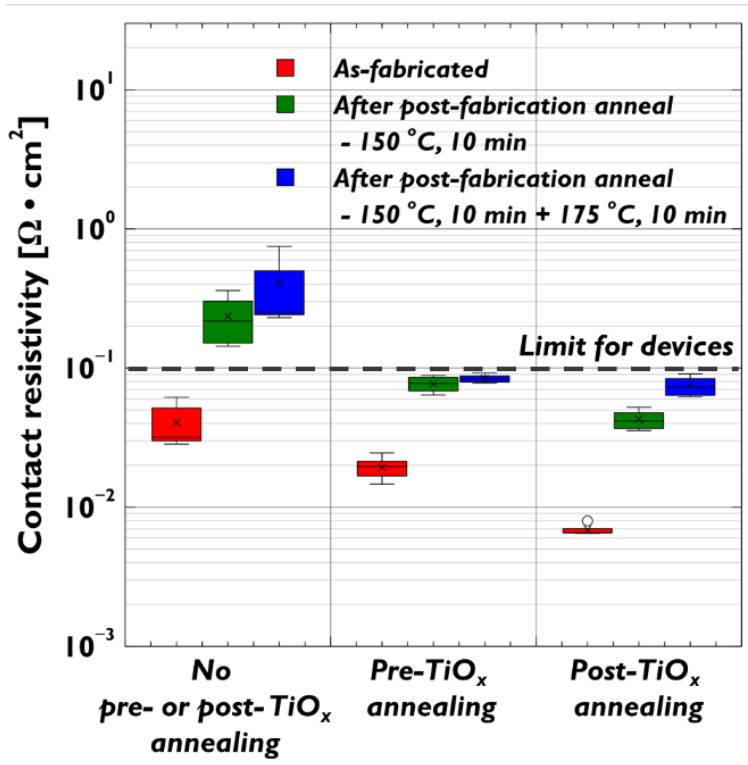

(b) Yb $30 \mathrm{~nm}$

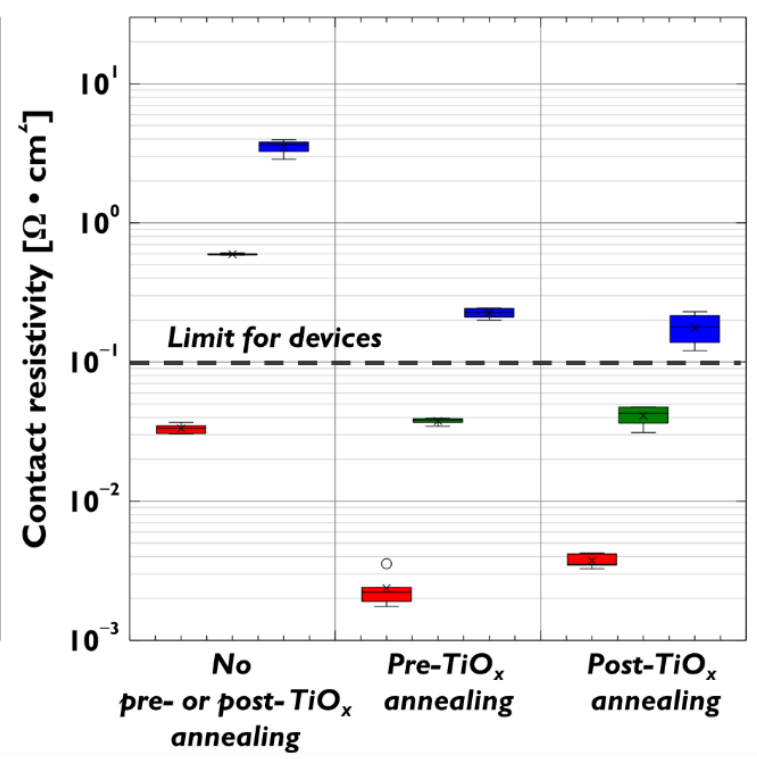

Figure 5. Evolution of contact resistivity $\left(\rho_{c}\right)$ after sequential post-fabrication anneals at $150{ }^{\circ} \mathrm{C}$ and $175{ }^{\circ} \mathrm{C}$ for 10 min each, for the three anneal groups shown in Figure 2 (i.e. no pre-or post-TiO $O_{x}$ annealing, pre-and-post-TiO $O_{x}$ annealing). Pre- and post-TiO $O_{x}$ anneals were done at $250{ }^{\circ} \mathrm{C}$. Results for ATOM contact with Yb thickness of (a) $7.5 \mathrm{~nm}$ and (b) $30 \mathrm{~nm}$, respectively, are plotted. Each bar contains five data points. The targetted $\rho_{c}$ for device implementation is below $0.1 \Omega . \mathrm{cm}^{2}$ (indicated by the dashed line).

The first observed trend is that the $\rho_{\mathrm{c}}$ of the ATOM contact increases after post-fabrication annealing treatments at $150{ }^{\circ} \mathrm{C}$ and $175^{\circ} \mathrm{C}$ for all investigated conditions. However, the extent of the degradation is much lower for the pre- and post- $\mathrm{TiO}_{\mathrm{x}}$ anneal splits compared to the nonannealed case without neither pre- or post- $\mathrm{TiO}_{\mathrm{x}}$ annealing. Analogous to studies on degradation of the $\rho_{c}$ of i-a-Si:H/MoO ${ }_{x}$ hole contacts [27], it appears that annealing the i-a-Si:H layer before capping it with thick metal layers is indeed also beneficial for the ATOM contact in ensuring higher thermal stability. As discussed in Section 3.1, annealing reduces the $\mathrm{H}$ content of the ia-Si:H layer, which mitigates the reaction between the $\mathrm{H}$ in $\mathrm{i}-\mathrm{a}-\mathrm{Si}: \mathrm{H}$ and $\mathrm{O}$ in $\mathrm{TiO}_{\mathrm{x}}$. In this 
respect, to maximize $\mathrm{O}$ concentration in $\mathrm{TiO}_{\mathrm{x}}$ by avoiding thermal treatment of $\mathrm{TiO}_{\mathrm{x}}$ as much as possible, the pre- $\mathrm{TiO}_{\mathrm{x}}$ annealing route would be more suitable than the post- $\mathrm{TiO}_{\mathrm{x}}$ annealing.

Comparing Figure 5 (a) with Figure 5 (b), a second trend that can be noticed is that for nonannealed $\mathrm{TiO}_{\mathrm{x}}$, thicker $\mathrm{Yb}$ causes a stronger degradation in $\rho_{\mathrm{c}}$ after post-fabrication annealing. In other words, thicker $\mathrm{Yb}$ seems to reduce $\mathrm{TiO}_{\mathrm{x}}$ more aggressively. According to $\mathrm{Fu}$ et al., oxygen transport to the interface from $\mathrm{TiO}_{2}$ to metal was dependent on the overlying metal work function [55]. They explained that the lower work function of a metal with respect to metal oxides promoted out-diffusion of oxygen from the metal oxides. A similar phenomenon was also found by Allen et al. whereby $\mathrm{TiO}_{\mathrm{x}}$ was reduced by $\mathrm{Ca}(\Phi 2.9 \mathrm{eV})$ and a $\mathrm{TiO}$ phase was detected by electron energy-loss spectroscopy (EELS) [37]. Since Yb has a work function of $2.5 \mathrm{eV}$, such oxygen migration at the interface between $\mathrm{TiO}_{\mathrm{x}}$ and $\mathrm{Yb}$ can be expected to be greater compared to the interface between $\mathrm{TiO}_{\mathrm{x}}$ and $\mathrm{Ca}$ or $\mathrm{Al}$ [37,55]. However, this phenomenon might be less severe for the case of thin $\mathrm{Yb}$, whose work function could be increased by the alloying of $\mathrm{Ag}$ and $\mathrm{Yb}[39,41]$. Thus, it is clear that using a thin $\mathrm{Yb}$ layer is beneficial in minimizing the thermal degradation of the ATOM contact.

The third trend that can be seen from Figure 5 is that both pre- and post- $\mathrm{TiO}_{\mathrm{x}}$ annealing treatments lower the $\rho_{c}$ compared to that of non-annealed samples before post-fabrication anneal treatments. We believe this is mainly related to structural and/or compositional changes to the i-a-Si:H layer. Dehydrogenation would lead to increased defects in a-Si:H, which could in turn increase trap-assisted tunneling through the $\mathrm{i}-\mathrm{a}-\mathrm{Si}: \mathrm{H}$.

Overall, for the case of $7.5 \mathrm{~nm}$ thick $\mathrm{Yb}$, the $\rho_{\mathrm{c}}$ values of the pre- and post- $\mathrm{TiO}_{\mathrm{x}}$ annealed samples were below the targetted threshold of $0.1 \Omega \cdot \mathrm{cm}^{2}$ after successive post-fabrication annealing treatment at $150{ }^{\circ} \mathrm{C}$ and $175^{\circ} \mathrm{C}$ while the non-annealed ATOM contact was already above the limit after the post-fabrication annealing even at $150{ }^{\circ} \mathrm{C}$. In conclusion, pre- $\mathrm{TiO}_{\mathrm{x}}$ annealing in combination with thin $\mathrm{Yb}$ should improve the thermal stability of ATOM contacts in terms of $\rho_{c}$.

\subsection{Impact of pre-TiO ${ }_{x}$ annealing on $\mathrm{iVoc}$ and $\mathrm{J}_{0, \text { total }}$ of MolyATOM cell pre-cursors}

Hydrogen in a-Si:H plays an important role in passivating the c-Si/a-Si interface. Thus, dehydrogenation of the $\mathrm{i}-\mathrm{a}-\mathrm{Si}: \mathrm{H}$ layer during pre- $\mathrm{TiO}_{\mathrm{x}}$ annealing can potentially affect the passivation quality of the $\mathrm{i}-\mathrm{a}-\mathrm{Si}: \mathrm{H}$ layer. This was verified by measuring the effective lifetime of MolyATOM cell pre-cursors (1) after pre- $\mathrm{TiO}_{\mathrm{x}}$ annealing, (2) after $\mathrm{TiO}_{\mathrm{x}}$ deposition and (3) after $\mathrm{MoO}_{\mathrm{x}}$ deposition, from which implied $\mathrm{V}_{\mathrm{OC}}\left(\mathrm{iV}_{\mathrm{OC}}\right)$ and $\mathrm{J}_{0 \text {,total }}$ can be determined. 


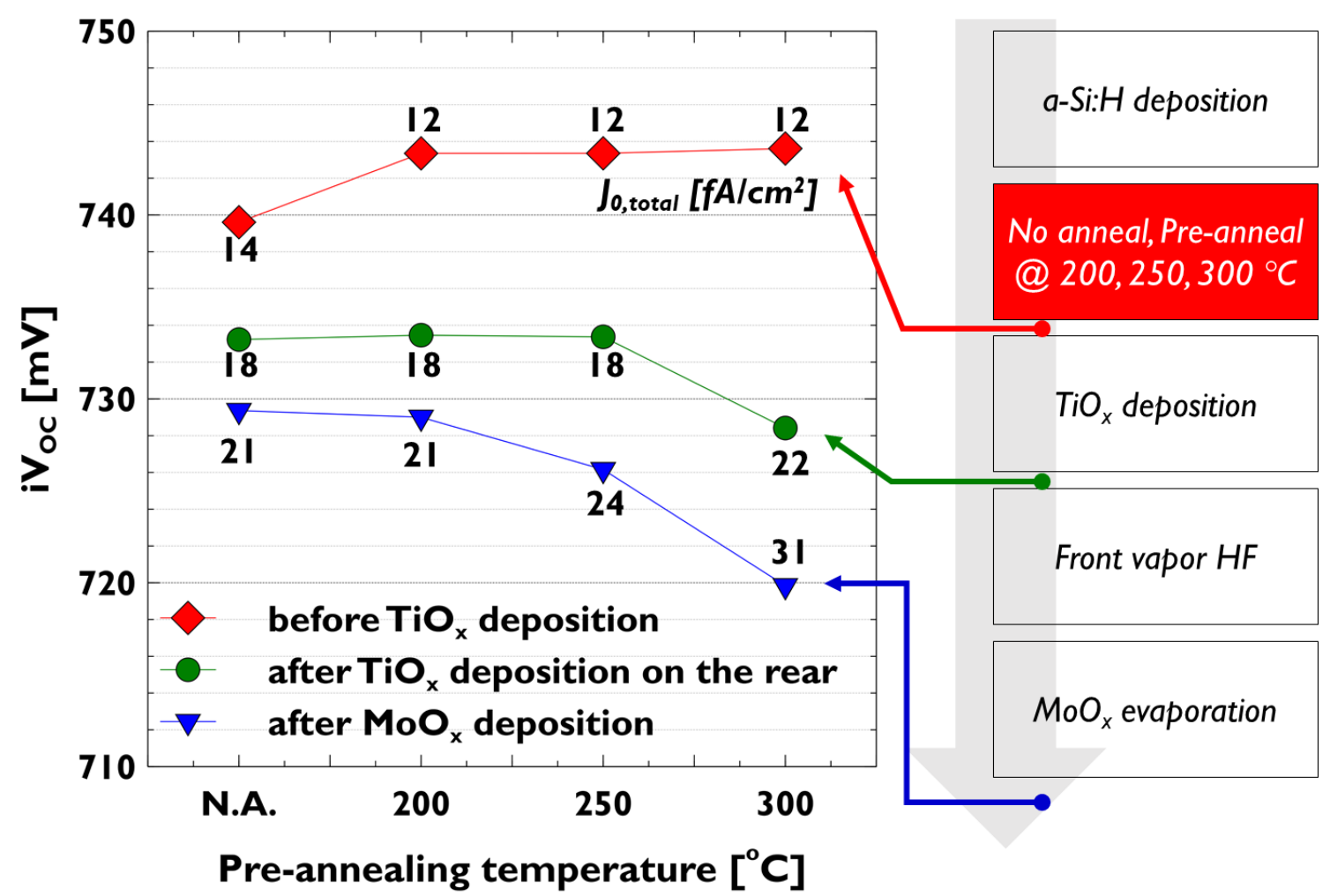

Figure 6. Progress in iVoc of pre-annealed or not-annealed samples at different process steps. The numbers in the figure are the $J_{0, \text { total }}$ values of samples based on a $J_{S C}$ of $36 \mathrm{~mA} / \mathrm{cm}^{2}$.

The evolution of $\mathrm{iV}_{\mathrm{OC}}$ and $\mathrm{J}_{0 \text {,total }}$ of the cell pre-cursors at different steps as a function of pre$\mathrm{TiO}_{\mathrm{x}}$ annealing temperature is shown in Figure 6. The passivation quality of annealed i-a-Si:H is similar to that of non-annealed $\mathrm{i}-\mathrm{a}-\mathrm{Si}-\mathrm{H}$, and high $\mathrm{iV}_{\mathrm{OC}}>740 \mathrm{mV}$ and low $\mathrm{J}_{0 \text {,total }}$ of $12 \mathrm{fA} / \mathrm{cm}^{2}$ are obtained for the cell pre-cursors with annealed i-a-Si:H. However, the deposition of $\mathrm{TiO}_{\mathrm{x}}$ results in a decrease of $\mathrm{i} \mathrm{V}_{\mathrm{OC}}$ of all splits, with the sample pre-annealed at $300{ }^{\circ} \mathrm{C}$ showing the strongest reduction in $\mathrm{iV}_{\mathrm{OC}}$. Similarly, the subsequent deposition of $\mathrm{MoO}_{\mathrm{x}}$ on the opposite side of the wafers leads to a further decrease in $\mathrm{i}_{\mathrm{OC}}$ of all splits. In addition, a decreasing trend in $\mathrm{iV}_{\mathrm{OC}}$ with pre- $\mathrm{TiO}_{\mathrm{x}}$ anneal temperature develops. Thus, we can conclude that pre-annealing treatment negatively impacts on the passivation quality after TMO depositions. Nevertheless, the $\mathrm{iV}_{\mathrm{OC}}$ of the worst sample is still $720 \mathrm{mV}$, which is promising for device implementation. Thus, the developed pre- $\mathrm{TiO}_{\mathrm{x}}$ annealing step was integrated into the device fabrication flow (see Figure 3).

\section{MolyATOM cells and comparison to classical SHJ cells}

\subsection{Impact of pre- $\mathrm{TiO}_{\mathrm{x}}$ annealing temperature on MolyATOM cell parameters}

In this section, we studied the impact of the pre- $\mathrm{TiO}_{\mathrm{x}}$ annealing temperature on the device parameters of the MolyATOM cell, particularly the fill factor (FF) and $\mathrm{V}_{\mathrm{OC}}$, which depend on the $\rho_{\mathrm{c}}$ and $\mathbf{J}_{0, \text { total }}$, respectively. 

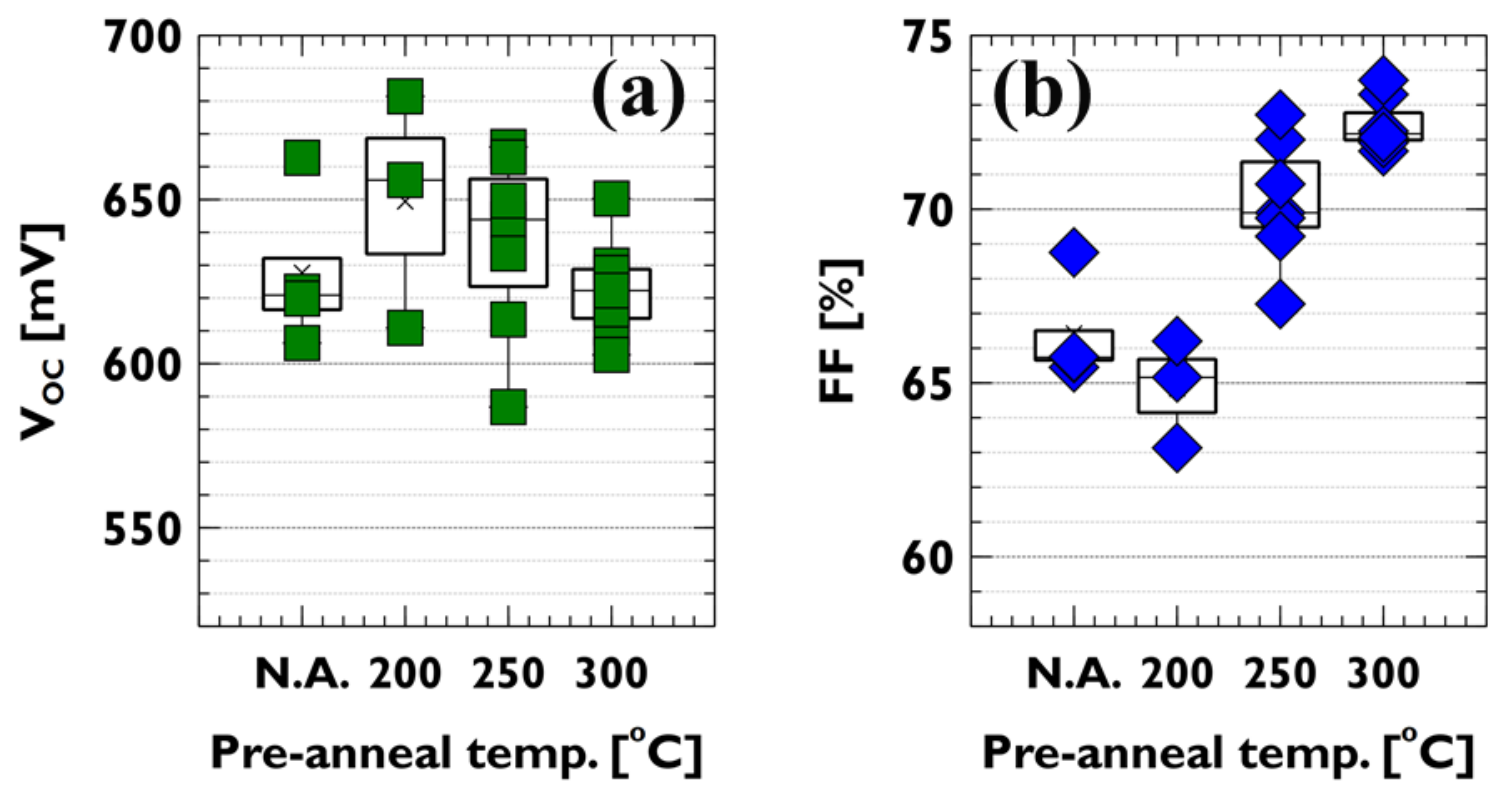

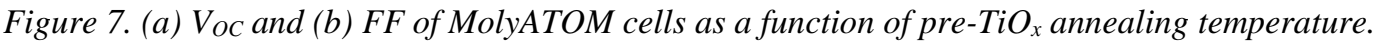

Table 2. Illuminated IV parameters of differentMolyATOM cells (average and best cell values).

\begin{tabular}{ccccccc}
\hline \multicolumn{2}{c}{$\begin{array}{c}\text { Pre-anneal temp. } \\
\text { (\# of sample) }\end{array}$} & $\begin{array}{c}\mathrm{J}_{\mathrm{SC}} \\
{\left[\mathrm{mA} / \mathrm{cm}^{2}\right]}\end{array}$ & $\begin{array}{c}\mathrm{V}_{\mathrm{OC}} \\
{[\mathrm{mV}]}\end{array}$ & $\begin{array}{c}\text { FF } \\
{[\%]}\end{array}$ & $\begin{array}{c}\text { Efficiency } \\
{[\%]}\end{array}$ & $\begin{array}{c}\mathrm{R}_{\mathrm{S}} \\
{\left[\Omega \cdot \mathrm{cm}^{2}\right]}\end{array}$ \\
\hline No & Average & $33.7 \pm 0.2$ & $628 \pm 24$ & $66.4 \pm 1.6$ & $14.1 \pm 1.0$ & $3.3 \pm 0.2$ \\
pre-anneal (4) & Best & 34.0 & 663 & 68.8 & 15.5 & 2.8 \\
& Average & $33.8 \pm 0.7$ & $649 \pm 36$ & $64.8 \pm 1.6$ & $14.3 \pm 1.4$ & $3.7 \pm 0.2$ \\
$200{ }^{\circ} \mathrm{C}(3)$ & Best & 34.2 & 681 & 66.2 & 15.4 & 3.6 \\
& Average & $33.5 \pm 0.5$ & $637 \pm 28$ & $70.2 \pm 1.8$ & $15.0 \pm 1.2$ & $2.5 \pm 0.5$ \\
$250{ }^{\circ} \mathrm{C}(7)$ & Best & 33.7 & 663 & 72.7 & 16.2 & 2 \\
& Average & $33.2 \pm 0.4$ & $623 \pm 15$ & $72.4 \pm 0.8$ & $15.0 \pm 0.7$ & $1.9 \pm 0.2$ \\
$300{ }^{\circ} \mathrm{C}(7)$ & Best & 33.9 & 650 & 73.7 & 16.3 & 1.7 \\
\hline
\end{tabular}

As shown in Figure 7 and Table 2, the VOC of the MolyATOM cells showed a weak dependence on pre-annealing temperature, as expected from the results of Figure 6. The non-annealed cells show a somewhat lower average $\mathrm{V}_{\mathrm{OC}}$ compared to the cells with pre- $\mathrm{TiO}_{\mathrm{x}}$ anneal, due to a less efficient hydrogen chemical passivation. Despite the different hydrogenation levels of the i-a$\mathrm{Si}: \mathrm{H}$ films, the passivation quality achieved at the device level is quite similar for all investigated conditions of pre- $\mathrm{TiO}_{\mathrm{x}}$ annealing. Nevertheless, the absolute $\mathrm{V}_{\mathrm{OC}}$ values are much lower compared to the $\mathrm{iV}_{\mathrm{OC}}$ values of Figure 6, indicating that the metallization process following $\mathrm{MoO}_{\mathrm{x}}$ deposition (see Figure 3) affects the passivation quality even further. More detailed comparison will be discussed in section 4.3.

On the other hand, a general trend in FF of the MolyATOM cells demonstrates a strong dependence with pre-annealing temperature, which again correlates well with the contact resistivity results of Section 3. Less hydrogen content in $\mathrm{i}-\mathrm{a}-\mathrm{Si}: \mathrm{H}$ after the pre-annealing 
treatment has a positive effect for the carrier collection, likely due to increased defects in the ia-Si:H layer, which aid trap-assisted conduction of charge carriers.

4.2. Dependence of thermal stability on pre-annealing temperature at cell level

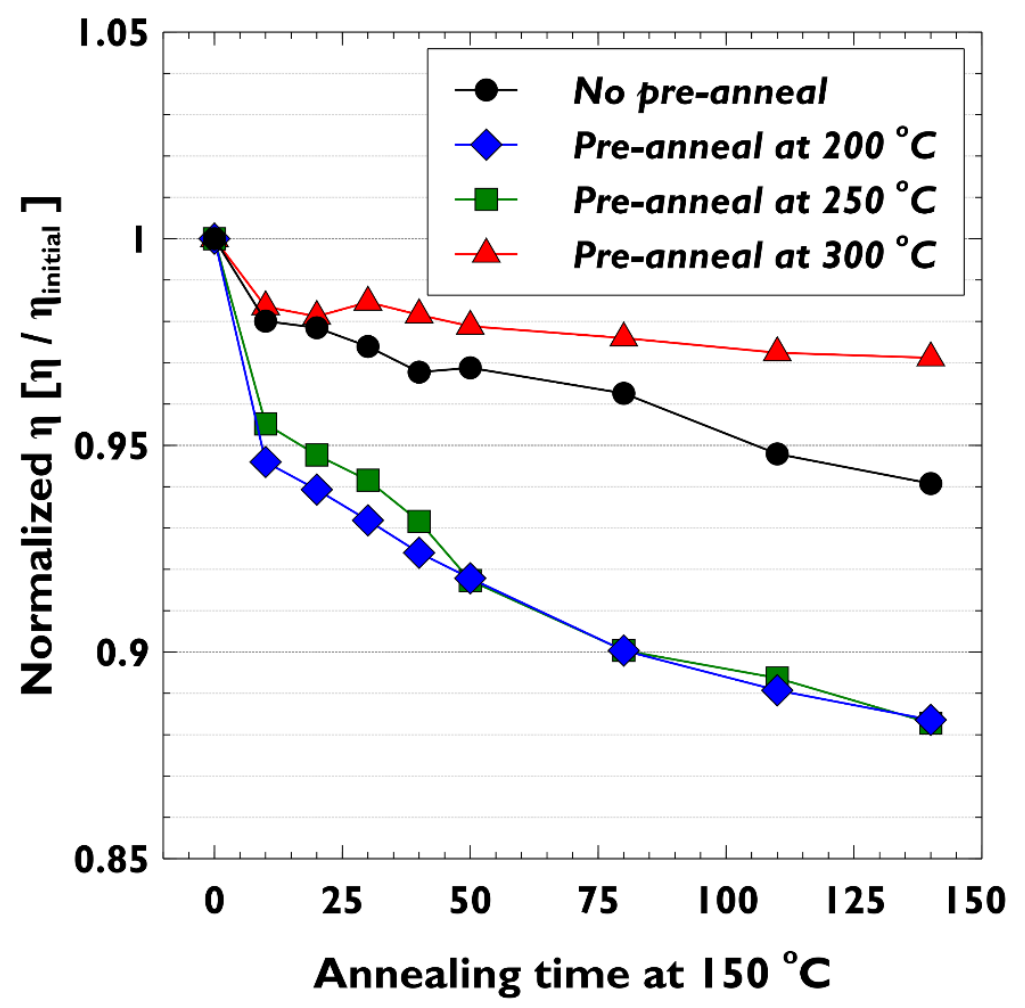

Figure 8. Efficiency progress as a function of annealing time at $150{ }^{\circ} \mathrm{C}$ in $\mathrm{N}_{2}$ atmosphere.

Since the pre-annealing of the $\mathrm{i}-\mathrm{a}-\mathrm{Si}: \mathrm{H}$ layer will affect both the ATOM contact and the $\mathrm{MoO}_{\mathrm{x}}$ based hole contact, the thermal stability was evaluated at device level using post-fabrication annealing at $150{ }^{\circ} \mathrm{C}$ for up to $140 \mathrm{~min}$ (see Figure 8). Cells with a pre- $\mathrm{TiO}_{\mathrm{x}}$ annealing at $300{ }^{\circ} \mathrm{C}$ remained relatively stable, while the other cells showed a continuous decrease in efficiency with increasing annealing time. The not pre-annealed MolyATOM cell looks stable due to their low initial efficiency of $13.4 \%$. The initial efficiency of other cells was in a range of $14.6 \%$ $15 \%$. We extracted a reduction rate in the efficiency of the cells using the last four data points where degradation occurred linearly. The cell with pre-TiOx annealing at $300{ }^{\circ} \mathrm{C}$ showed a reduction rate less than one-third of that of the cell without pre-annealing.

Based on the above results, the pre- $\mathrm{TiO}_{\mathrm{x}}$ annealing temperature for MolyATOM device integration was chosen to be $300{ }^{\circ} \mathrm{C}$ for the study in section 4.3 in which we compare MolyATOM cells with other cell varieties.

\subsection{Confirmation of improved thermal stability of MolyATOM cells at module level}

The thermal stability of MolyATOM cells with and without pre-annealing at $300{ }^{\circ} \mathrm{C}$ was compared at cell and module level. To check the thermal stability at cell level, post-fabrication 
annealing was done at $150{ }^{\circ} \mathrm{C}$ using the MolyATOM cells as shown in Figure 8. In addition, thermal stability of the MolyATOM cells at module level was investigated though the standard damp-heat testing (1000 hour, $85 \%$ humidity, $85^{\circ} \mathrm{C}$ ). The MolyATOM cells with and without pre-annealing treatment at $300^{\circ} \mathrm{C}$, shown in Figure 7, were used for fabricating a module. Performance of the mini-module was regularly measured every 250 hour during damp-heat test.
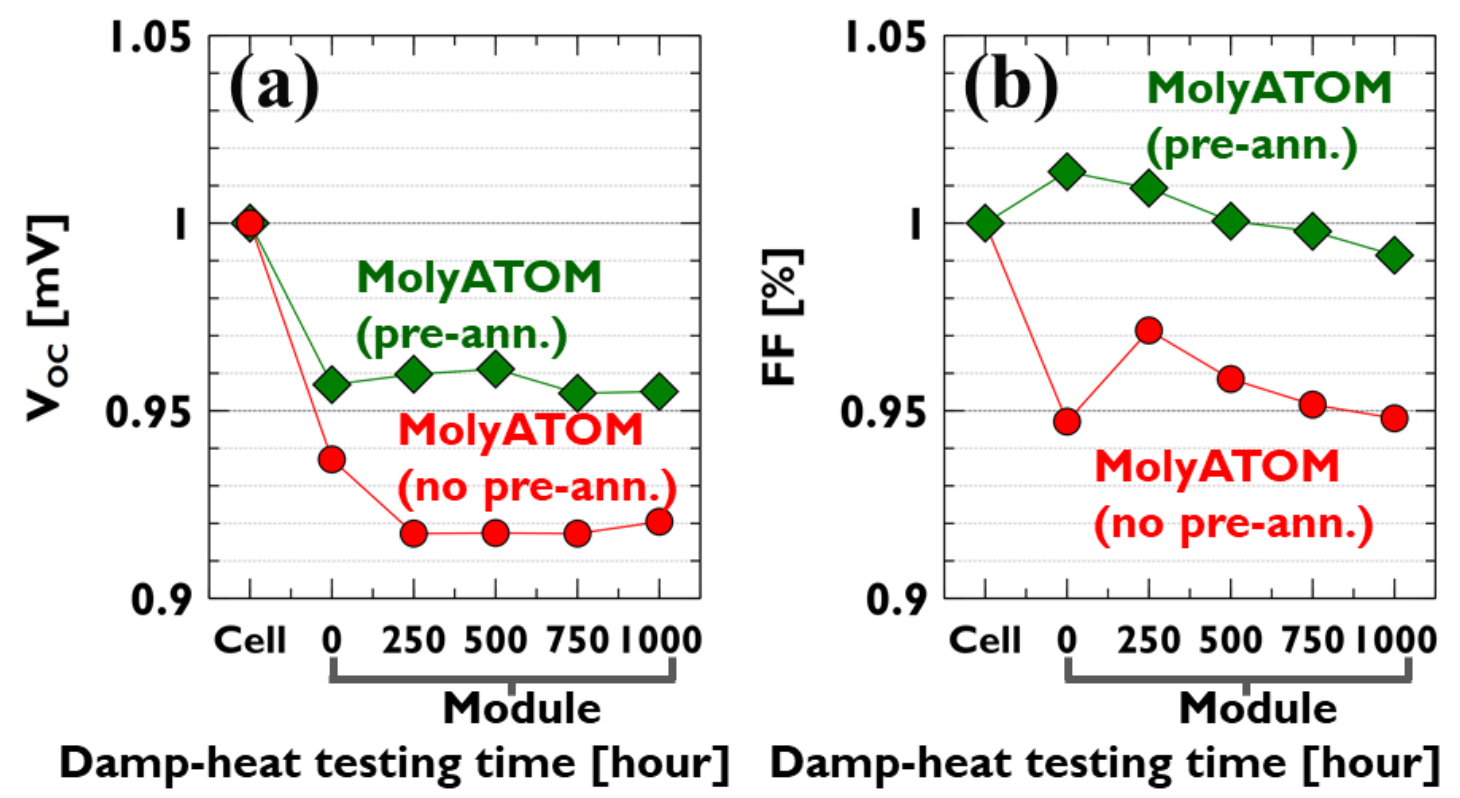

Figure 9. Thermal stability of MolyATOM cells at a module level. Progress in (a) VoC and (b) FF during the dampheat test.

During module fabrication, additional heat treatment due to the lamination process lowered the $\mathrm{V}_{\text {OC }}$ of both MolyATOM cells compared to the as-fabricated values (Figure 9 (a)). However, during the damp heat testing, the $\mathrm{V}_{\mathrm{OC}}$ of the non-pre-annealed MolyATOM cell degraded further while that of the pre-annealed MolyATOM cell remained stable throughout the testing duration.

The FF of the pre-annealed MolyATOM cell during the damp heat testing (Figure 9 (b)) showed a similar evolution as that of the FF of the cell during the thermal stability test at cell level, which is a noticeable reduction after annealing at $150{ }^{\circ} \mathrm{C}$ for $10 \mathrm{~min}$ (Figure 8). Starting at DH $0 \mathrm{~h}$, there is a gradual decrease in FF for the pre-annealed MolyATOM cell. The cell without pre-anneal though showed an anomalous behavior, with an increase in FF at DH $250 \mathrm{~h}$, followed then by a gradual decrease in FF till DH $1000 \mathrm{~h}$. Based on these results, we did not observe a significant difference in the thermal stability in terms of FF of the MolyATOM cells due to preannealing (DH $0 \mathrm{~h}$ vs DH $1000 \mathrm{~h}$ ). Nevertheless, considering all the thermal stability results together, we can conclude that pre-annealing the $\mathrm{i}-\mathrm{a}-\mathrm{Si}: \mathrm{H}$ during cell processing is beneficial for the thermal stability of MolyATOM cells. More generally, reducing the hydrogen content in the thin film contact stacks is helpful when using metals oxides. After the damp-heat test, the final efficiency was decreased by about $2.4 \%$ rel compared to that measured at DH $0 \mathrm{~h}$. It meant 
that the stability of MolyATOM cell at the module was passing the criteria of IEC61215 $(\eta<$ $5 \%$ rel).

\subsection{Relative performance of MolyATOM cells compared to other cell types}

To study relative performance, several types of solar cells were newly prepared. In Figure 10 and Table 3, MolyATOM cell parameters are compared with classical SHJ- and Moly/in cells. For the Moly/in cells, 2 splits of cells with and without pre-annealing treatment at $300{ }^{\circ} \mathrm{C}$ are also shown. For MolyATOM cells, only pre-annealed cells were prepared. In addition, the published results of cells having i/p-a-Si:H based hole contacts and ATOM electron contacts (i.e. ip/ATOM cells) have been included in Figure 10 [41]. Note that a different Ti precursor for $\mathrm{TiO}_{\mathrm{x}}$ and thicker $\mathrm{Yb}$ of $40 \mathrm{~nm}$ were used for these ip/ATOM cells [41]. The other ATOM contacts had $7.5 \mathrm{~nm}$ thick $\mathrm{Yb}$.
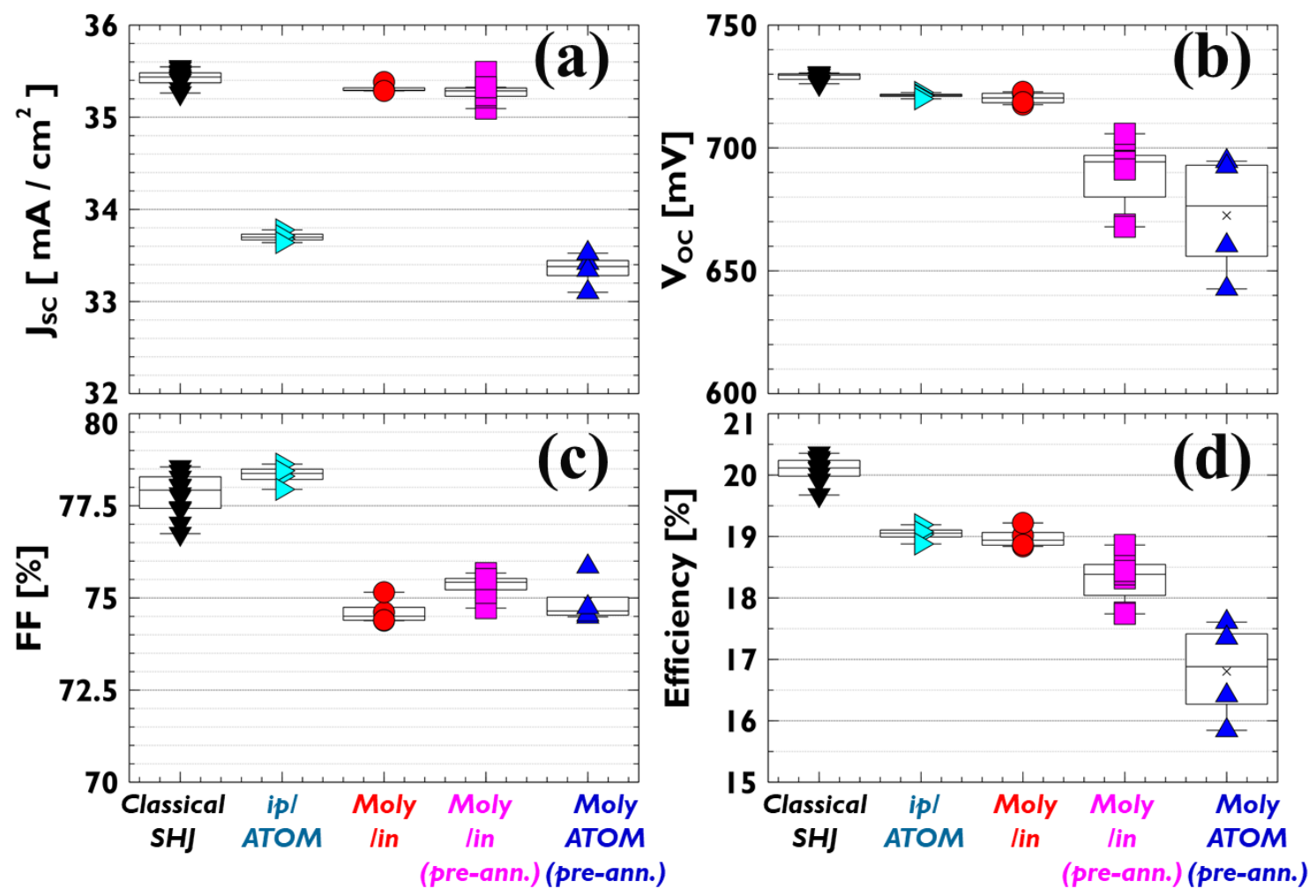

Figure 10. Performance comparison between classical SHJ, partial-doping free (Moly/in) and fully doping-free cells (MolyATOM). (a) $J_{S C}$, (b) VOC, (c) FF and (d) efficiency. ip/ATOM data is from [41]. 
Table 3. The average and the best cell results of each solar cell group shown in Figure 10. Data for ip/ATOM is taken from [41].

\begin{tabular}{ccccccc}
\hline \multicolumn{2}{c}{$\begin{array}{c}\text { Solar cell structure } \\
\text { (\# of sample) }\end{array}$} & $\begin{array}{c}\mathrm{J}_{\mathrm{SC}} \\
{\left[\mathrm{mA} / \mathrm{cm}^{2}\right]}\end{array}$ & $\begin{array}{c}\mathrm{V}_{\mathrm{OC}} \\
{[\mathrm{mV}]}\end{array}$ & $\begin{array}{c}\mathrm{FF} \\
{[\%]}\end{array}$ & $\begin{array}{c}\text { Efficiency } \\
{[\%]}\end{array}$ & $\begin{array}{c}\mathrm{R}_{\mathrm{S}} \\
{\left[\Omega \cdot \mathrm{cm}^{2}\right]}\end{array}$ \\
\hline \multirow{2}{*}{ Classical SHJ (12) } & Average & $35.5 \pm 0.1$ & $729 \pm 2$ & $77.7 \pm 0.6$ & $20.1 \pm 0.2$ & $1.4 \pm 0.1$ \\
ip/ATOM & Best & 35.5 & 730 & 78.6 & 20.4 & 1.3 \\
(4) [41] & Average & $33.7 \pm 0.1$ & $721 \pm 1$ & $78.3 \pm 0.3$ & $19.0 \pm 0.1$ & $1.0 \pm 0.0$ \\
& Best & 33.8 & 723 & 78.6 & 19.2 & 1.0 \\
Moly/in (4) & Average & $35.3 \pm 0.0$ & $720 \pm 3$ & $74.6 \pm 0.4$ & $19.0 \pm 0.2$ & $1.9 \pm 0.1$ \\
& Best & 35.4 & 723 & 75.2 & 19.2 & 1.8 \\
Moly/in & Average & $35.3 \pm 0.1$ & $689 \pm 15$ & $75.3 \pm 0.3$ & $18.3 \pm 0.4$ & $1.4 \pm 0.1$ \\
(Pre-ann.) (7) & Best & 35.5 & 706 & 75.3 & 18.9 & 1.4 \\
MolyATOM & Average & $33.3 \pm 0.2$ & $673 \pm 25$ & $74.9 \pm 0.6$ & $16.8 \pm 0.8$ & $1.4 \pm 0.0$ \\
(pre-ann.) (4) & Best & 33.4 & 695 & 75.8 & 17.6 & 1.3 \\
\hline
\end{tabular}

The $\mathrm{J}_{\mathrm{SC}}$ of the cells is drastically affected by the electron contact structure on the rear-side of the cells. A conventional i/n-a-Si:H/ITO/Ag electron contact at the rear-side of classical SHJ and Moly/in cells resulted in higher $\mathrm{J}_{\mathrm{SC}}$ compared to that of MolyATOM and ip/ATOM cells. Moreover, Moly/in cells do not exhibit a higher $\mathrm{J}_{\mathrm{SC}}$ compared to the classical SHJ cells.To understand these differences, the EQE and reflectance of the different cell types were compared in Figure 11. 


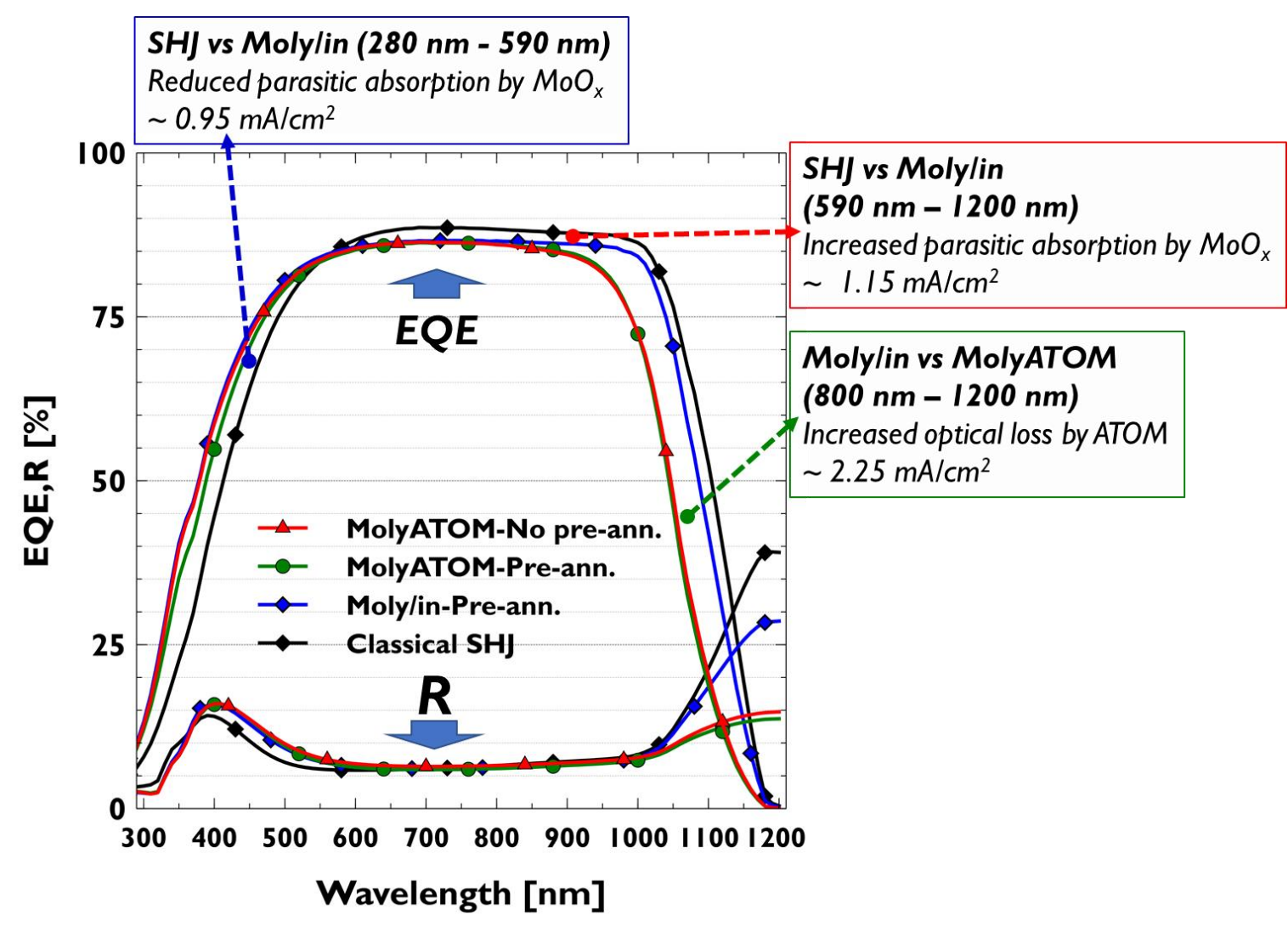

Figure 11. EQE and reflectance comparison between different cell structures; MolyATOM cell with/without preannealing treatment, Moly/in- and a classical SHJ cell.

Figure 11 shows that the cells with $\mathrm{MoO}_{\mathrm{x}}$ based hole contacts exhibited higher EQE in the short wavelength region compared to the classical SHJ cells containing p-a-Si:H. However, this did not result in a higher $\mathrm{J}_{\mathrm{SC}}$ for the Moly/in cells due to a lower EQE in the middle and longwavelength regions compared to the classical SHJ cells, which is the result of parasitic absorption in $\mathrm{MoO}_{\mathrm{x}}$, as reported in [20]. A pre-annealing treatment does not change the EQE of the Moly/in cell (data is not shown here). Thus, transparent $\mathrm{MoO}_{\mathrm{x}}$ needs to be developed for getting higher $\mathrm{J}_{\mathrm{SC}}$ in Moly/in cells relative to classical SHJ cells. For the MolyATOM cells, lower EQE is observed at long wavelengths, which coincides with lower reflectance compared to the Moly/in or classical SHJ cells. This is expected to be mainly due to the proximity of the metal to the c-Si in the ATOM contact structure, which results in the excitation of surface plasmon polaritons, causing parasitic infrared light absorption losses. For the Moly/in and classical SHJ cells, on the other hand, ITO acts as a buffer layer.

As shown in Figure 10 (b), classical SHJ cells showed the highest VOC among the test groups. When doping-free contacts were applied separately, $\mathrm{V}_{\text {OC }}$ of ip/ATOM and Moly/in were above $720 \mathrm{mV}$ on average. For Moly/in cells, the pre-annealing condition used might not be the optimal due to the fact that pre-annealed cells showed lower $V_{\text {OC. Different contact structure }}$ likely needs different thermal treatment condition. When combining $\mathrm{MoO}_{\mathrm{x}}$-based hole and ATOM electron contacts into the same device, an additional $\mathrm{V}_{\mathrm{OC}}$ drop was observed. It is 
believed that this reduction in $\mathrm{V}_{\mathrm{OC}}$ might be caused due to integration difficulties when combining the two different doping-free contacts. For example, to deposit $\mathrm{TiO}_{\mathrm{x}}, 300 \mathrm{~mm}$ diameter carrier wafers with a $200 \mathrm{~mm}$ round inner pocket, had to be used. During this loading of wafers on such carriers, the i-a-Si:H passivation layer on the front side of MolyATOM wafers touch the surface of carrier wafers, which may lead to contamination or scratches. A second possibility could be that the vapor HF, utilized in the case of MolyATOM cells, might not be sufficient to clean the surface of the wafers.

In Figure 10 (c), the average FF of ip/ATOM cells of about $78.3 \%$ is higher compared to that of the classical SHJ cells which is $77.8 \%$. However, when replacing the p-a-Si:H layer with $\mathrm{MoO}_{\mathrm{x}}$, a reduction in FF of about $3.2 \%$ abs with respect to classical SHJ cell was observed. The FF was not further decreased for the MolyATOM cells thanks to the pre-annealing treatment in the cell process. The pre-annealing treatment of MolyATOM cells and Moly/in cells effectively reached the average $\mathrm{R}_{S}$ of $1.4 \Omega \cdot \mathrm{cm}^{2}$ and $1.4 \Omega \cdot \mathrm{cm}^{2}$, respectively, which is at a similar level to that in classical SHJ cells $\left(\mathrm{R}_{\mathrm{S}} \sim 1.4 \Omega \cdot \mathrm{cm}^{2}\right)$. This gain in FF and $\mathrm{R}_{\mathrm{S}}$ due to pre-annealing treatment mostly come from the hole-contact side because $\rho_{c}$ of the ATOM contact is lower than the limit of $0.1 \Omega \cdot \mathrm{cm}^{2}$.

The champion MolyATOM cell achieved an efficiency of $17.6 \%$ with Jsc of $33.4 \mathrm{~mA} / \mathrm{cm}^{2}$, $\mathrm{V}_{\text {OC }}$ of $695 \mathrm{mV}$ and FF of $75.8 \%$, for an active cell area of $16 \mathrm{~cm}^{2}$. So far, SHJ cells with doped a-Si:H layers at both electron and hole contacts outperform the MolyATOM cells. Overall, the gap in performance between MolyATOM and classical SHJ cells was observed and needs to be reduced. Thus, for the MolyATOM cells, good optical rear reflectance and stronger band bending at the ATOM electron contact, as well as lower $\mathrm{R}_{\mathrm{S}}$ at the $\mathrm{MoO}_{\mathrm{x}}$ based hole contact with higher transmittance and higher workfunction need to be achieved to attain similar or better performance compared to classical SHJ cells.

\section{Conclusion}

We have investigated the impact of annealing $\mathrm{i}-\mathrm{a}-\mathrm{Si}: \mathrm{H}$ on the thermal stability of an electron contact featuring i-a- $-\mathrm{Si}: \mathrm{H} / \underline{T i O}_{\mathrm{x}} /$ low work function metal (ATOM). Like $\mathrm{MoO}_{\mathrm{x}} / \mathrm{i}-\mathrm{a}-\mathrm{Si}: \mathrm{H}$ based hole contacts, annealing the $\mathrm{i}-\mathrm{a}-\mathrm{Si}: \mathrm{H}$ layer before metal oxide deposition (i.e. pre-annealing treatment) was helpful to increase the thermal stability of the ATOM contact. Doping-free cells, called MolyATOM cells, were prepared using both $\mathrm{MoO}_{\mathrm{x}} / \mathrm{i}-\mathrm{a}-\mathrm{Si}: \mathrm{H}$ based hole contacts and ATOM based electron contacts. The champion cell fabricated with pre-annealing treatment at $300{ }^{\circ} \mathrm{C}$ for $20 \mathrm{~min}$ achieved a $\mathrm{J}_{\mathrm{SC}}$ of $33.4 \mathrm{~mA} / \mathrm{cm}^{2}$, a $\mathrm{V}_{\mathrm{OC}}$ of $695 \mathrm{mV}$, a FF of $75.8 \%$ and an efficiency of $17.6 \%$ with a cell area of $16 \mathrm{~cm}^{2}$. High efficiencies and improved thermal stability of pre-annealed MolyATOM cells were confirmed at the cell as well as module level. It is believed that hydrogen-related degradation was mitigated by the pre-annealing treatment. The hydrogen content in $\mathrm{i}-\mathrm{a}-\mathrm{Si}: \mathrm{H}$ was decreased from $15.7 \%$ to $11.4 \%$ after pre-annealing treatment at $300^{\circ} \mathrm{C}$ according to elastic recoil detection measurements. The insights of this study will also be useful for developing another novel stable and highly performing metal-oxide based electron or hole contacts. 


\section{Acknowledgments}

The authors thank Praveen Dara and Johan Meersschaut for ERD measurement. Moreover, the authors gratefully acknowledge the financial support of imec's industrial affiliation program for Si-PV. The work in this paper was partially funded by the Kuwait Foundation for the Advancement of Sciences under project number CN18-15EE-01. Imec is a partner in EnergyVille (www.energyville.be), a collaboration between the Flemish research partners KU Leuven, VITO, imec, and UHasselt in the field of sustainable energy and intelligent energy systems. 


\section{References}

[1] M. Schmela, R. Rossi, M. Schmela, A. Beauvais, N. Chevillard, M.G. Paredes, M. Heisz, R. Rossi, M. Schmela, Global Market Outlook for Solar Power 2019-2023, 2019.

[2] S. Philipps, W. Warmuth, Fraunhofer ISE Photovoltaics Report, updated: 14 March 2019, 2019.

[3] A. Metz, G. Demenik, A. Richter, International Technology Roadmap for Photovoltaic (ITRPV), 2019. 2 http://www.itrpv.net/.cm4all/iproc.php/Reports downloads/ITRPV_2015_Roadmap_Results_2014_150428.pdf?cdp=a.

[4] ITRPV, ITRPV 10th edition 2019 - report release and key findings, (2019) 1-28.

[5] A. Cuevas, P.A. Basore, G. Giroult-Matlakowski, C. Dubois, Surface recombination velocity of highly doped $\mathrm{n}$-type silicon, J. Appl. Phys. 80 (1996) 3370-3375. doi:10.1063/1.363250.

[6] E. Franklin, K. Fong, K. McIntosh, A. Fell, A. Blakers, T. Kho, D. Walter, D. Wang, N. Zin, M. Stocks, E.-C. Wang, N. Grant, Y. Wan, Y. Yang, X. Zhang, Z. Feng, P.J. Verlinden, Design, fabrication and characterisation of a $24.4 \%$ efficient interdigitated back contact solar cell, Prog. Photovoltaics Res. Appl. 24 (2016) 411-427. doi:10.1002/pip.2556.

[7] Y. Tomizawa, Y. Ikeda, H. Itoh, T. Shiro, J. Loffler, P. Manshanden, I. Romijn, Analysis of contact recombination at rear local back surface field via boron laser doping and screen-printed aluminum metallization on p-type PERC solar cells, Energy Procedia. 124 (2017) 384-391. doi:10.1016/j.egypro.2017.09.256.

[8] T. Fellmeth, A. Born, A. Kimmerle, F. Clement, D. Biro, R. Preu, Recombination at metal-emitter interfaces of front contact technologies for highly efficient silicon solar cells, Energy Procedia. 8 (2011) 115-121. doi:10.1016/j.egypro.2011.06.111.

[9] F. Ye, W. Deng, W. Guo, R. Liu, D. Chen, Y. Chen, Y. Yang, N. Yuan, J. Ding, Z. Feng, P.P. Altermatt, P.J. Verlinden, 22.13\% Efficient industrial p-type mono PERC solar cell, in: 2016 IEEE 43rd Photovolt. Spec. Conf., IEEE, 2016: pp. 3360-3365. doi:10.1109/PVSC.2016.7750289.

[10] J. Cho, H.-N.-R. Shin, J. Lee, Y. Choi, J. Lee, H. Oh, T. Kim, M. Hwang, E.-C. Cho, 21\%-Efficient n-type Rear-junction PERT Solar Cell with Industrial Thin $156 \mathrm{~mm} \mathrm{Cz}$ Single Crystalline Silicon Wafer, Energy Procedia. 77 (2015) 279-285. doi:10.1016/j.egypro.2015.07.039.

[11] J. Schmidt, R. Peibst, R. Brendel, Surface passivation of crystalline silicon solar cells: Present and future, Sol. Energy Mater. Sol. Cells. 187 (2018) 39-54. doi:10.1016/j.solmat.2018.06.047.

[12] K. Yamamoto, K. Yoshikawa, H. Uzu, D. Adachi, High-efficiency heterojunction crystalline Si solar cells, Jpn. J. Appl. Phys. 57 (2018). doi:10.7567/JJAP.57.08RB20.

[13] G. Nogay, J.P. Seif, Y. Riesen, A. Tomasi, L. Barraud, N. Wyrsch, F.-J. Haug, S. De Wolf, C. Ballif, Notice of Removal Microcrystalline silicon carrier collectors for silicon heterojunction solar cells and impact on low-temperature device characteristics, in: 2017 IEEE 44th Photovolt. Spec. Conf., IEEE, 2017: pp. 1-3. doi:10.1109/PVSC.2017.8366840.

[14] F. Haase, C. Hollemann, S. Schäfer, A. Merkle, M. Rienäcker, J. Krügener, R. Brendel, R. Peibst, Laser contact openings for local poly-Si-metal contacts enabling $26.1 \%$ efficient POLO-IBC solar cells, Sol. Energy Mater. Sol. Cells. 186 (2018) 184-193. doi:10.1016/j.solmat.2018.06.020.

[15] F. Feldmann, M. Bivour, C. Reichel, H. Steinkemper, M. Hermle, S.W. Glunz, Tunnel 
oxide passivated contacts as an alternative to partial rear contacts, Sol. Energy Mater. Sol. Cells. 131 (2014) 46-50. doi:10.1016/j.solmat.2014.06.015.

[16] A. Richter, J. Benick, F. Feldmann, A. Fell, M. Hermle, S.W. Glunz, n-Type Si solar cells with passivating electron contact: Identifying sources for efficiency limitations by wafer thickness and resistivity variation, Sol. Energy Mater. Sol. Cells. 173 (2017) 96105. doi:10.1016/j.solmat.2017.05.042.

[17] M. Osborne, Jolywood supplying SPIC with N-type TOPCon bifacial modules, PV-Tech. (2018). https://www.pv-tech.org/news/jolywood-supplying-spic-with-n-type-topconbifacial-modules.

[18] O. Almora, L.G. Gerling, C. Voz, R. Alcubilla, J. Puigdollers, G. Garcia-Belmonte, Superior performance of V2O5 as hole selective contact over other transition metal oxides in silicon heterojunction solar cells, Sol. Energy Mater. Sol. Cells. 168 (2017) 221-226. doi:10.1016/j.solmat.2017.04.042.

[19] L.G. Gerling, S. Mahato, A. Morales-Vilches, G. Masmitja, P. Ortega, C. Voz, R. Alcubilla, J. Puigdollers, Transition metal oxides as hole-selective contacts in silicon heterojunctions solar cells, Sol. Energy Mater. Sol. Cells. 145 (2016) 109-115. doi:10.1016/j.solmat.2015.08.028.

[20] J. Cho, N. Nawal, A. Hadipour, M. Recaman Payo, A. van der Heide, H.S. Radhakrishnan, M. Debucquoy, I. Gordon, J. Szlufcik, J. Poortmans, Interface analysis and intrinsic thermal stability of $\mathrm{MoOx}$ based hole-selective contacts for silicon heterojunction solar cells, Sol. Energy Mater. Sol. Cells. 201 (2019) 110074. doi:10.1016/j.solmat.2019.110074.

[21] K. Gotoh, M. Cui, N.C. Thanh, K. Koyama, I. Takahashi, Y. Kurokawa, H. Matsumura, N. Usami, Fabrication of CuI/a-Si:H/c-Si Structure for Application to Hole-selective Contacts of Heterojunction Si Solar Cells, in: 44th IEEE Photovoltaics Spec. Conf., 2017: pp. 4-7.

[22] J. Geissbühler, J. Werner, S. Martin De Nicolas, L. Barraud, A. Hessler-Wyser, M. Despeisse, S. Nicolay, A. Tomasi, B. Niesen, S. De Wolf, C. Ballif, 22.5\% efficient silicon heterojunction solar cell with molybdenum oxide hole collector, Appl. Phys. Lett. 107 (2015) 081601. doi:10.1063/1.4928747.

[23] W. Wu, W. Lin, S. Zhong, B. Paviet-Salomon, M. Despeisse, Z. Liang, M. Boccard, H. Shen, C. Ballif, 22\% Efficient Dopant-Free Interdigitated Back Contact Silicon Solar Cells, AIP Conf. Proc. 1999 (2018) 1-7. doi:10.1063/1.5049288.

[24] D. Sacchetto, Q. Jeangros, G. Christmann, L. Barraud, A. Descoeudres, J. Geissbuhler, M. Despeisse, A. Hessler-Wyser, S. Nicolay, C. Ballif, ITO/MoOx/a-Si:H(i) HoleSelective Contacts for Silicon Heterojunction Solar Cells: Degradation Mechanisms and Cell Integration, IEEE J. Photovoltaics. 7 (2017) 1584-1590. doi:10.1109/JPHOTOV.2017.2756066.

[25] J. Bullock, Y. Wan, Z. Xu, S. Essig, M. Hettick, H. Wang, W. Ji, M. Boccard, A. Cuevas, C. Ballif, A. Javey, Stable Dopant-Free Asymmetric Heterocontact Silicon Solar Cells with Efficiencies above 20\%, ACS Energy Lett. 3 (2018) 508-513. doi:10.1021/acsenergylett.7b01279.

[26] L. Neusel, M. Bivour, M. Hermle, Selectivity issues of MoOx based hole contacts, in: SiliconPV Conf. 2017, 2017: pp. 425-434. doi:10.1016/j.egypro.2017.09.268.

[27] S. Essig, J. Dréon, E. Rucavado, M. Mews, T. Koida, M. Boccard, J. Werner, J. Geissbühler, P. Löper, M. Morales-Masis, L. Korte, S. De Wolf, C. Ballif, Toward Annealing-Stable Molybdenum-Oxide-Based Hole-Selective Contacts For Silicon Photovoltaics, Sol. RRL. 2 (2018) 1700227. doi:10.1002/solr.201700227. 
[28] X. Yang, Q. Bi, H. Ali, K. Davis, W. V Schoenfeld, K. Weber, High-Performance TiO2 -Based Electron-Selective Contacts for Crystalline Silicon Solar Cells., Adv. Mater. (2016). doi:10.1002/adma.201600926.

[29] X. Yang, Q. Bi, H. Ali, K. Davis, W. V Schoenfeld, K. Weber, High-Performance TiO2Based Electron-Selective Contacts for Crystalline Silicon Solar Cells, Adv. Mater. 28 (2016) 5891-5897. doi:10.1002/adma.201600926.

[30] V. Titova, J. Schmidt, Implementation of full-area-deposited electron-selective TiO $x$ layers into silicon solar cells, AIP Adv. 8 (2018) 125023. doi:10.1063/1.5061924.

[31] Y. Wan, S.K. Karuturi, C. Samundsett, J. Bullock, M. Hettick, D. Yan, J. Peng, P.R. Narangari, S. Mokkapati, H.H. Tan, C. Jagadish, A. Javey, A. Cuevas, Tantalum Oxide Electron-Selective Heterocontacts for Silicon Photovoltaics and Photoelectrochemical Water Reduction, ACS Energy Lett. 3 (2018) 125-131. doi:10.1021/acsenergylett.7b01153.

[32] X. Yang, E. Aydin, H. Xu, J. Kang, M. Hedhili, W. Liu, Y. Wan, J. Peng, C. Samundsett, A. Cuevas, S. De Wolf, Tantalum Nitride Electron-Selective Contact for Crystalline Silicon Solar Cells, Adv. Energy Mater. $8 \quad$ (2018) 1800608. doi:10.1002/aenm.201800608.

[33] X. Yang, W. Liu, M. De Bastiani, T. Allen, J. Kang, H. Xu, E. Aydin, L. Xu, Q. Bi, H. Dang, E. AlHabshi, K. Kotsovos, A. AlSaggaf, I. Gereige, Y. Wan, J. Peng, C. Samundsett, A. Cuevas, S. De Wolf, Dual-Function Electron-Conductive, HoleBlocking Titanium Nitride Contacts for Efficient Silicon Solar Cells, Joule. 3 (2019) 1314-1327. doi:10.1016/j.joule.2019.03.008.

[34] J. Bullock, P. Zheng, Q. Jeangros, M. Tosun, M. Hettick, C.M. Sutter-Fella, Y. Wan, T. Allen, D. Yan, D. Macdonald, S. De Wolf, A. Hessler-Wyser, A. Cuevas, A. Javey, Lithium Fluoride Based Electron Contacts for High Efficiency n-Type Crystalline Silicon Solar Cells, Adv. Energy Mater. 6 (2016). doi:10.1002/aenm.201600241.

[35] J. Bullock, Y. Wan, M. Hettick, X. Zhaoran, S.P. Phang, D. Yan, H. Wang, W. Ji, C. Samundsett, Z. Hameiri, D. Macdonald, A. Cuevas, A. Javey, Dopant-Free Partial Rear Contacts Enabling 23\% Silicon Solar Cells, Adv. Energy Mater. 9 (2019) 1-6. doi:10.1002/aenm.201803367.

[36] Y. Wan, C. Samundsett, J. Bullock, T. Allen, M. Hettick, D. Yan, P. Zheng, X. Zhang, J. Cui, J. McKeon, A. Javey, A. Cuevas, Magnesium Fluoride Electron-Selective Contacts for Crystalline Silicon Solar Cells, ACS Appl. Mater. Interfaces. 8 (2016) 14671-14677. doi:10.1021/acsami.6b03599.

[37] T.G. Allen, J. Bullock, Q. Jeangros, C. Samundsett, Y. Wan, J. Cui, A. Hessler-Wyser, S. De Wolf, A. Javey, A. Cuevas, A Low Resistance Calcium/Reduced Titania Passivated Contact for High Efficiency Crystalline Silicon Solar Cells, Adv. Energy Mater. 7 (2017) 1602606. doi:10.1002/aenm.201602606.

[38] J. Cho, M. Debucquoy, M. Recaman Payo, S. Malik, M. Filipič, H.S. Radhakrishnan, T. Bearda, I. Gordon, J. Szlufcik, J. Poortmans, Contact resistivity reduction on lowlydoped n-type Si using a low work function metal and a thin TiOX interfacial layer for doping-free Si solar cells, Energy Procedia. $124 \quad$ (2017) 842-850. doi:10.1016/j.egypro.2017.09.356.

[39] J. Cho, M.R. Payo, M. Debucquoy, H.S. Radhakrishnan, I. Gordon, J. Szlufcik, M. Ghannam, J. Poortmans, Electron-selective contact using i-a-Si:H/TiOx/Yb/Ag stack for silicon heterojunction solar cells, in: 35th Eur. Photovolt. Sol. Energy Conf. Exhib., 2018: pp. 431-433. doi:10.4229/35thEUPVSEC20182018-2CO.11.5.

[40] J. Cho, J. Melskens, M. Debucquoy, M. Recamán Payo, S. Jambaldinni, T. Bearda, I. 
Gordon, J. Szlufcik, W.M.M. Kessels, J. Poortmans, Passivating electron-selective contacts for silicon solar cells based on an a-Si:H/TiOx stack and a low work function metal, Prog. Photovoltaics Res. Appl. 26 (2018) 835-845. doi:10.1002/pip.3023.

[41] J. Cho, J. Melskens, M.R. Payo, M. Debucquoy, H.S. Radhakrishnan, I. Gordon, J. Szlufcik, W.M.M.M. Kessels, J. Poortmans, Performance and Thermal Stability of an a$\mathrm{Si}: \mathrm{H} / \mathrm{TiO}$ x /Yb Stack as an Electron-Selective Contact in Silicon Heterojunction Solar Cells, ACS Appl. Energy Mater. 2 (2019) 1393-1404. doi:10.1021/acsaem.8b01969.

[42] S. Zhong, M. Morales-Masis, M. Mews, L. Korte, Q. Jeangros, W. Wu, M. Boccard, C. Ballif, Exploring co-sputtering of $\mathrm{ZnO}: \mathrm{Al}$ and $\mathrm{SiO} 2$ for efficient electron-selective contacts on silicon solar cells, Sol. Energy Mater. Sol. Cells. 194 (2019) 67-73. doi:10.1016/j.solmat.2019.02.005.

[43] B. Macco, L.E. Black, J. Melskens, B.W.H. van de Loo, W.H. Berghuis, M.A. Verheijen, W.M.M. Kessels, Atomic-layer deposited Nb $2 \mathrm{O} 5$ as transparent passivating electron contact for c-Si solar cells, Sol. Energy Mater. Sol. Cells. 184 (2018) 98-104. doi:10.1016/j.solmat.2018.04.037.

[44] M. Liu, Y. Zhou, G. Dong, W. Wang, J. Wang, C. Liu, F. Liu, D. Yu, SnO2/Mg combination electron selective transport layer for Si heterojunction solar cells, Sol. Energy Mater. Sol. Cells. 200 (2019) 109996. doi:10.1016/j.solmat.2019.109996.

[45] C.R. Wronski, D.E. Carlson, Surface states and barrier heights of metal-amorphous silicon schottky barriers, Solid State Commun. 23 (1977) 421-424. doi:10.1016/00381098(77)90999-1.

[46] W. Mönch, Electronic Properties of Semiconductor Interfaces, Springer, 2004.

[47] A. Agrawal, J. Lin, M. Barth, R. White, B. Zheng, S. Chopra, S. Gupta, K. Wang, J. Gelatos, S.E. Mohney, S. Datta, Fermi level depinning and contact resistivity reduction using a reduced titania interlayer in n-silicon metal-insulator-semiconductor ohmic contacts, Appl. Phys. Lett. 104 (2014) 112101. doi:10.1063/1.4868302.

[48] J. Cho, M. Debucquoy, M. Recaman Payo, S. Malik, M. Filipič, H.S. Radhakrishnan, T. Bearda, I. Gordon, J. Szlufcik, J. Poortmans, Contact resistivity reduction on lowlydoped n-type Si using a low work function metal and a thin TiOx interfacial layer for doping-free $\mathrm{Si}$ solar cells, in: SiliconPV Conf. 2017, 2017: pp. 842-850. doi:10.1016/j.egypro.2017.09.356.

[49] J. Cho, M. Debucquoy, M.R. Payo, E. Schapmans, I. Gordon, J. Szlufcik, J. Poortmans, Evidence of $\mathrm{TiOx}$ reduction at the $\mathrm{SiOx} / \mathrm{TiOx}$ interface of passivating electron-selective contacts, in: SiliconPV Conf. 2018, 2018: p. 040005. doi:10.1063/1.5049268.

[50] H. Yu, M. Schaekers, T. Schram, S. Demuynck, N. Horiguchi, K. Barla, N. Collaert, A.V.-Y. Thean, K. De Meyer, Thermal Stability Concern of Metal-InsulatorSemiconductor Contact: A Case Study of Ti/TiO 2 /n-Si Contact, IEEE Trans. Electron Devices. 63 (2016) 2671-2676. doi:10.1109/TED.2016.2565565.

[51] A. Borgschulte, O. Sambalova, R. Delmelle, S. Jenatsch, R. Hany, F. Nüesch, Hydrogen reduction of molybdenum oxide at room temperature, Sci. Rep. 7 (2017) 40761. doi:10.1038/srep40761.

[52] M.T. Greiner, L. Chai, M.G. Helander, W.M. Tang, Z.H. Lu, Transition metal oxide work functions: The influence of cation oxidation state and oxygen vacancies, Adv. Funct. Mater. 22 (2012) 4557-4568. doi:10.1002/adfm.201200615.

[53] M.A. Green, A.W. Blakers, J. Zhao, A.M. Milne, A. Wang, X. Dai, Characterization of 23-percent efficient silicon solar cells, IEEE Trans. Electron Devices. 37 (1990) 331336. doi:10.1109/16.46361.

[54] S.W. Glunz, J. Nekarda, H. Mäckel, A. Cuevas, Analyzing Back Contacts of Silicon 
Solar Cells by Suns-Voc-Measurements at High Illumination Densities, in: Proc. 22nd Eur. Photovolt. Sol. Energy Conf. 3-7 Sept. 2007, Milan, Italy, 2007: pp. 849-853.

[55] Q. Fu, T. Wagner, Metal/oxide interfacial reactions: Oxidation of metals on SrTiO3 (100) and TiO2 (110), J. Phys. Chem. B. 109 (2005) 11697-11705. doi:10.1021/jp050601i. 